\title{
Energy release and seismic flux
}

\author{
J. M. MunueRA
}

Ricevuto il 27 Aprile 1965

Summary. - From the basic data and the previous results of prior papers, we have made evaluations of the energy released and studied its variation. Its pulsative form is confirmed, which suggests several superposed periods, perhaps of simple multiples of the undecenal of solar activity. For steps of a whole unity of $m$, the total approximated energy is computed. $E N$ and $E_{\ell}$ may be compared, it being possible to replace one by the other, indifferently, from $m=5$ up to $m=7.5$. The compared variation of log $E N$ with $N$ demostrates they are not proportional.

The tectonic flux is evaluated and we have the graphs for 5 and 15 year lapses, from 1901 to 1960 , as well as another graph which corresponds to the representative average of these 60 years. A reduction of the map of seismic activity attained through $\log (\Sigma E)^{1 / 2}: 60 \times 2.5$ is attached, which refers the annual flux for every $1000 \mathrm{sq} \mathrm{km}$. This map is analyzed and the comparative results with the zones of the first seismotectonic sketch published by Rey Pastor (1927) are considered. The conformity is checked and the differences are shown.

With Benioff's curve, expressed by $10^{11}(\mathrm{erg})^{1 / 2}$, we show the accumulation and release of the total elastic strain, $\Sigma_{60}(\Sigma E)^{1 / 2}$ and $(\Sigma E)^{1 / 2}$ for every year of the instrumental period (1901-1960). The cumulative interval (half a Century) coincides with the return period of the destructive earthquakes, which was estimated through other considerations.

We have made a comparative sketch between seismic activity and the admitted drawing of the Alpine Geosyncline on the Western Mediterreanean and we suggest a possible rough-draft of the Oval regression at its Western end. The alignments of the intermediate shocks, in the Alboran Sea and the Betican rogion, indicate active faults which might associated, perhaps, in a half-close as another oval connected to the Guadalquivir Fault and Southwards.

The comparison of the seismicity with the regional tectonics of the whole area agrees in general speaking, and this shows that the major part of the seismic activity occurs in the interior of the Geosyncline; however, we also note seismic activity in the Platform, which could be explained by the tectonic elements. A sketch of Bouguer's gravimetric anomalies and another one of the horizontal geomagnetic isodynamics, both of the Iberian 
Peninsula only, are used for the comparison of the results of the seismic activity map. Together with the tectonic data, these two maps contribute to the explanation of the seismicity in the area. The isostatic discompensation, as shown by sans and Lozano, agrees with the location in Bailen of two intermediate focei of 1951, which Bonelli and Esteban Carrasco studied. Gravimetry and Geomagnetism agree with the tectonic facies as well as with the seismicity of the Platform, to the SW.

Lastly, several comments are made with regard to the attained results and to the most interesting problems posed in the seismic study. Also several questions are brought up which require wider research based on instrumental, abundant and accurate data, especially, for Seno Gaditano, the Alboran sea and for the seismie lagoon of Ibiza.

Riassuxio. - Sulla base dei dati e dei risultati di precedenti note, ì stata valutata l'energia sviluppata studiandone la variazione; viene confermato il suo carattere pulsante, clse presuppone più periodi sovrapposti, forse multipli semplici del periodo unlecennale dell'attivita solare. î stata inoltre calcolata l'energia totale approssinnta per frazioni di $m$ (intera). $E N$ può essere paragonata ad $E_{t}$, essendo possibile sostituire indifferentemente una allalta, per valori di $m$. compresi fra 5 e 7,5 . Confrontando la variazione del $\log E N$ con $N$, si dimostra che essi non sono proporzionali.

Si è valutato il flusso tettonico e sono stati fatti grafici per intervalli di 5 e 15 anni dal 1901 al 1960, e un altro grafico che corrisponde alla media di questi 60 anni. Si acclude alla nota, una carta ridotta dell'attivita sismica ottemuta usando $\varnothing=\log (\Sigma E)^{1 / 2} 60 \times 2,5$, che rappresenta il flusso anmuale per ogni mille $\mathrm{km}^{2}$. Quest'ultima viene analizzata e i risultati sono confrontati eon quelli del primo schema sismotettonico pubblicato da Rey Pastor (1927). L'accumulo dello sviluppo della tensione elastica totale $\Sigma_{60}\left(\sum E\right)^{1 / 2}$ e di $\left(\sum E\right)^{1} / 2$, estato rappresentato per ogni anno, dal 1901 al 1960, mediante la curva di Benioff espressa in $10^{11}(\mathrm{erg})^{1} / 2.11$ periodo di accumulo (mezzo secolo), coincide con il periodo di ritorno di terremoti distruttivi, che è stato calcolato altrimenti.

İ stata quindi fatta una cartina di confronto fra lattivita sismica e il traceiato ammesso per la Geosinclinale Alpina nel Mediterraneo Occidentale, e l'A. propone un possibile andanento della regressione "Ovale "verso il suo limite occidentale. Gli allineamenti delle seosse intermedie nel Mar di Alboran e nella Regione Betica, inclicano faglie attive che potrebbero associarsi, forse, ad un'altra "Ovale " connessa alla faglia del Guadalquivir e alla zona meridionale.

Generalmente, la sismicità e la tettonica regionale dell'intera area sono in accordo, mettendo in evidenza che la maggior parte dell'attivita sismica av viene nell'interno della Geosinclinale; in ogni caso, si nota anche attivita sismica nella "Piattaforma", (he potrebbe essere spiegata con gli elenenti tettonici. Lo schizzo delle anomalie rravimetriche di Boudruer e fuello delle isodinamiche geomagnetiche orizontali, ambedue limitati alla Penisola Iberiea, sono utilizzati per un confronto con la carta dellattiviti sismica. Insieme con i dati tettonici, queste due carte contribuiscono a spiegare la sismicita in detta zona. Lo scompenso isostatico, segualato da Sans e Lozano, si ac. 
corda con la localizzazione presso Bailen di due "fuochi " intermedi (1951), studiati da Bonelli e Esteban Carrasco. (iravimetria e geomagnetismo coincidono con le caratteristiche tettoniche e con la sismiciti della "Piattaforma " a str.

Infine vengono commentati i risultati ottenuti e i problemi più interessanti lo studio sismico, e si segnalano altri problemi che richiedono ricerche piu ampie, basate su copiosi e precisi dati strumentali: specialmente per quanto riguarda il Seno Gaditano, il Mar di Alboran e la Laguna sismica di Ibi\%a.

Rxtracto. - Con los datos básicos y resultados previos de trabajos anteriores se hacen evaluaciones de la energía liberada $y$ se estudia su variacion. Sie confirma su forma pulsatoria que sugiere varios periodos superpuestos, quizá de múltiplos sencillos del undecenal de la actividad solar. se determina la energia total aproximada, para intervalos de una unidad entera de $m$. Se comparan $E N, E_{t}$, que pueden tomarse una por otra, indiferentemente. entre $m$ desde 5 a 7.5 . La variación comparada $\log E N$, con $N$, conduce a la dedución de que no son proporcionales.

Se evalúa el flujo tectónico y se presentan gráficos para lapsos de 5 y 15 años, desde 1901 a 1960 , así como otro gráfico correspondiente al promedio representativo de esos 60 años. Se adjunta una reducción del mapa de actividad sísmica obtenido con $\varnothing=\log \frac{(\Sigma E)}{60 \times a .5}$ que se refiere al flujo anual por cada $10^{3} \mathrm{~km}^{2}$. Se analiza ese mapa $\mathrm{y}$ se discuten los resultados comparativos con las zonas del primer croquis sismotectónico que publicó Rey-Pastor (1927). Se comprueba una buena conformidad $y$ se describen las diferencias.

Con la curva de Benioff, expresada en $10^{11}(\mathrm{erg})^{1 / 2}$ se presenta la acumulación y liberación de la deformación elástica unitaria total $\Sigma_{60}(\Sigma E)^{1 / 2}$ y de $\left(\sum E\right)^{1 / 2}$ para cada uno de los años del periodo instrumental (1901-1960). El intervalo de acumulación (medio siglo) coincide con el periodo de retorno para los sismos destructores, que fué estimado por consideraciones diferentes.

Se hace un bosquejo comparativo entre la activilad sísmica y el trazado admitido para el Geosinclinal Alpino en el Mediterráneo Occidental y se sugiere un posible esbozo de la reversión del Ovalo, en su límite W. Las alineaciones de sismos de profundidad intermedia, en la región Betica $y$ en el Mar de Alborán, denuncian fracturas activas que podrian asociarse, tal vez, en un entorno cerrado, a modo de otro óvalo insertado en la Falla del Guadalquivir $y$ al Sur.

La comparación de la sismicidad con la tectónica regional de toda el área concuerda en líneas generales, y demuestra que la mayor parte de la actividad sísmica ocurre en el interior del Geosinclinal; sin embargo, se aprecia tambien actividad sismica en la Plataforma, que parece explicarse por los elementos tectónicos. Ln croquis de las anomalias gravimétricas de Bougner y otro le las isodinámicas geomagnetios horizontales, ambos para la Península solanente, se utilizan para comparar los resultados del mapa de actividad sísmica. Juntamente con los datos tectónicos; esos dos mapas, contribuyen a explicar la sismicidad del área. La descompensación 
isostática señalada por Sans y Lozano concuerda con la localización de los dos focos intermedios de 1951, estudiados por Bonelli y Esteban Carrasco, en Bailén. Gravimetría y Geomagnetismo coinciden con la facies tectónica y con la sismicidad de la Plataforma, al SW.

Finalmente, se hacen breves comentarios sobre los resultados alcanzados y los problemas más interesantes que se plantean en todo el estudio sísmico y se señalan algunas de las cuestiones que requieren investigaciones más amplias, basadas en datos instrumentales abundantes y precisos. Singularmente, para el Seno Gaditano, Mar de Alborán y en la laguna sísmica de Ibiza.

\section{I. - Introduction.}

In the present paper, with the purpose of helping to obtain some seismic features in the region boundered by $10^{\circ} \mathrm{W}-5^{\circ} \mathrm{E}$ and $35^{\circ}-44^{\circ} \mathrm{N}$, the data and prior results published in former papers are made use of here (see Ref. $a, b, c, d)\left(^{*}\right)$.

\section{II. - SEISMIC ENERGY RELEASE. \\ 1. Energy EN.}

From the empirical expression $\log E=a+b \cdot M$, the numerical values for the parameters $a, b$, were deduced as an average obtained through the application, for $M$ of from 3 up to 9 , several formulas proposed by different authors (Table I). After substituting $I f$ for the modified magnitude $m$, we have

$$
\log E=3.79+2.65 m
$$

which will be used here to evaluate the energy of one earthquake and also for the energy of $N$ earthquakes of the same magnitude $(\log E N)$.

In this way the values quoted in Table II (1801-1960) grouped in lusters as shown in Fig. 1, have been deduced. The magnitude assigned to each earthquake is a consequence of applying the ESC's formula (1962), which expresses $M$ in function of $I_{0}, h$, and for this reason groups by steps of a half unity of $m$ were made, as stated in Ref. $c$ ).

The figure shows a graphic straight adjustment in order to obtain more homogeneity for ordinates, since the increase in the information with time is obvious. The noticeable points and also the quiet-sun years, $Q S$, are noted and we can advise:

a) $25,40,20,40$, years as intervals between minima (average $31.3)$, 
b) $40,30,25,45$, years as intervals between principal maxima $(35.0)$,

c) 40, 25, 30, years as intervals between secondary maxima (31.7),

d) the secondary maxima appear every time after the main maximum and there are no noticeable points between minima and the contiguous main maximum,

Table I - Several empirical formulas $\log E\left(^{*}\right)$

\begin{tabular}{|c|c|c|c|c|}
\hline Reference & Author & \multicolumn{3}{|c|}{$\log E$} \\
\hline$A$ & $\begin{array}{c}\text { Båth } \\
n \\
n\end{array}$ & $\begin{array}{c}10.2 \\
8.9 \\
12.24\end{array}$ & $\begin{array}{l}+1.6 \\
+\quad 1.6 \\
+\quad 1.44\end{array}$ & $\begin{array}{l}M I \\
M \\
M I\end{array}$ \\
\hline B & $\underset{n}{\text { Benioff }}$ & $\begin{array}{r}10.43 \\
9.00\end{array}$ & $\begin{array}{l}+1.73 \\
+1.8\end{array}$ & $\begin{array}{l}\text { MI } \\
M \Gamma(* *)\end{array}$ \\
\hline $\mathrm{C}$ & Di Nilippo \& Marcelli & 9.154 & +1.47 & $M \Gamma$ \\
\hline $\mathrm{D}$ & $\underset{\|}{\text { Gutenberg } \& \text { Richter }}$ & $\begin{array}{l}11.00 \\
11.3\end{array}$ & $\begin{array}{l}+1.60 \\
+1.50\end{array}$ & $\begin{array}{l}M I \\
M\end{array}$ \\
\hline $\mathrm{E}$ & Rothé & 11.44 & +1.50 & $M$ \\
\hline $\mathbf{F}$ & Solovyov & 11.50 & +1.50 & $\mathrm{M}$ \\
\hline
\end{tabular}

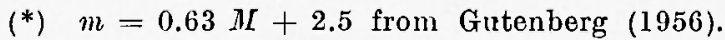

(**) Utilized by Niazi (1964).

(*) Munuera J. M., Caracteres mecanicos de los sismos. RU, 255-256, Tarragona, (1962).

Munuera J. M., Seismic Data. MIGC, XXXII, 1, Madrid, (1963).

Munuera J., Epicentres and Frequency. MIGC, XXXIII, 4, Madrid, (1964). - A seismic probability map. AG, XVII, 4, Roma, (1964).

e) between 1835.1840 and 1955.1960 the graph admits a mental rotation around an axis which is perpendicular to the plane of the drawing (i.e. for 1890-1895). The positive and the negative areas clearly, coincide with each other with respect to the adjustment line: +1955 , $-1840 ;-1925.1950,+1845.1870 ;+1910,-1880$ and $-1900,+1885$,

f) the coincidence of the maxima of 1855,1910 with $Q S$, with no other correlation between the noticeable points and $Q S$.

The figure is not appropriate for a Fourier analysis, as the ordinates are uncertain, but its form suggests several close dephased periods, perhaps of some simple multiples of the undecenal of solar activity. 
'Table II -.. ENenci sisce 1801 up To 1960.

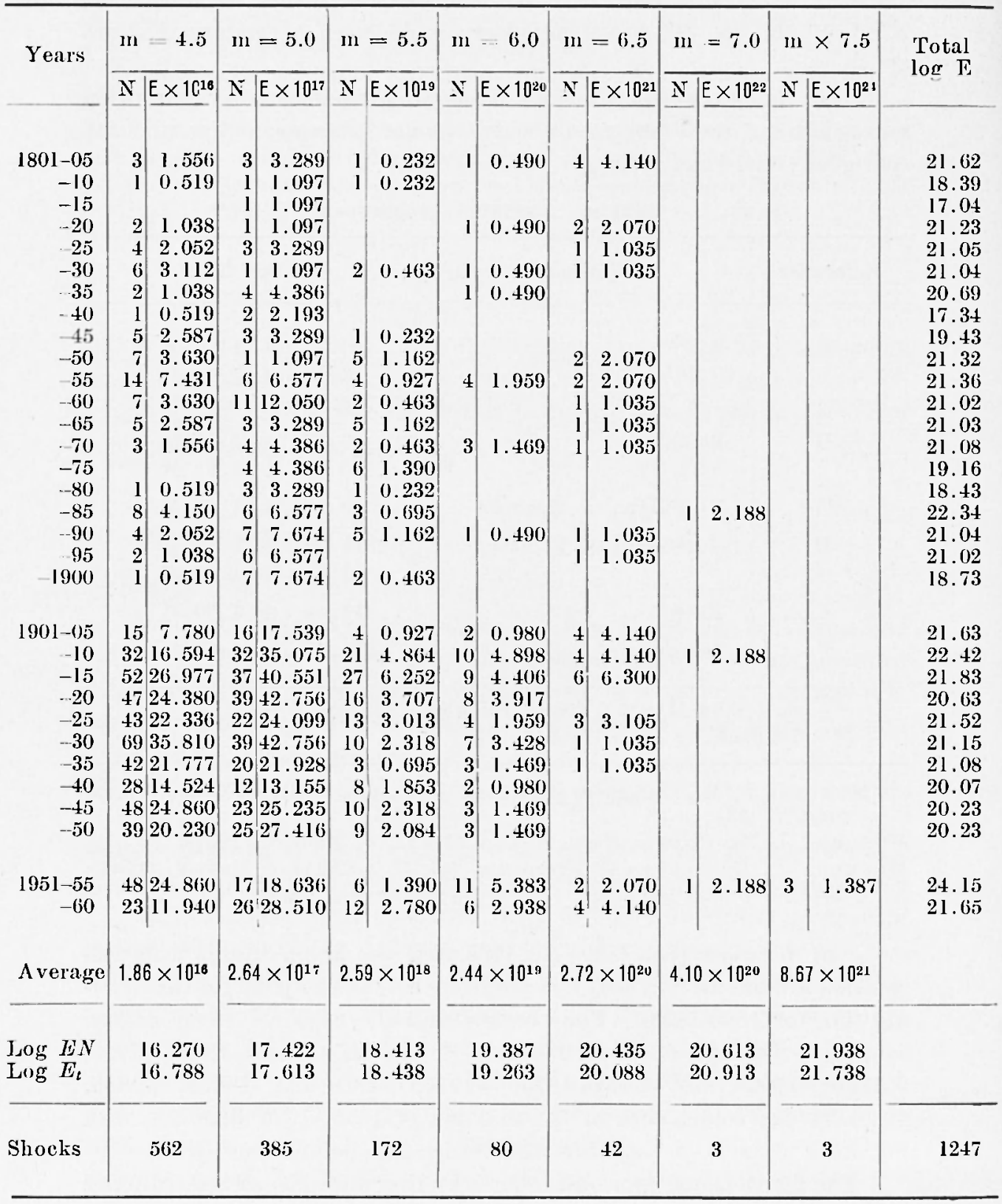

Total energy released during 160 years $\approx 1.5 \times 10^{24}$ erg, approximately 


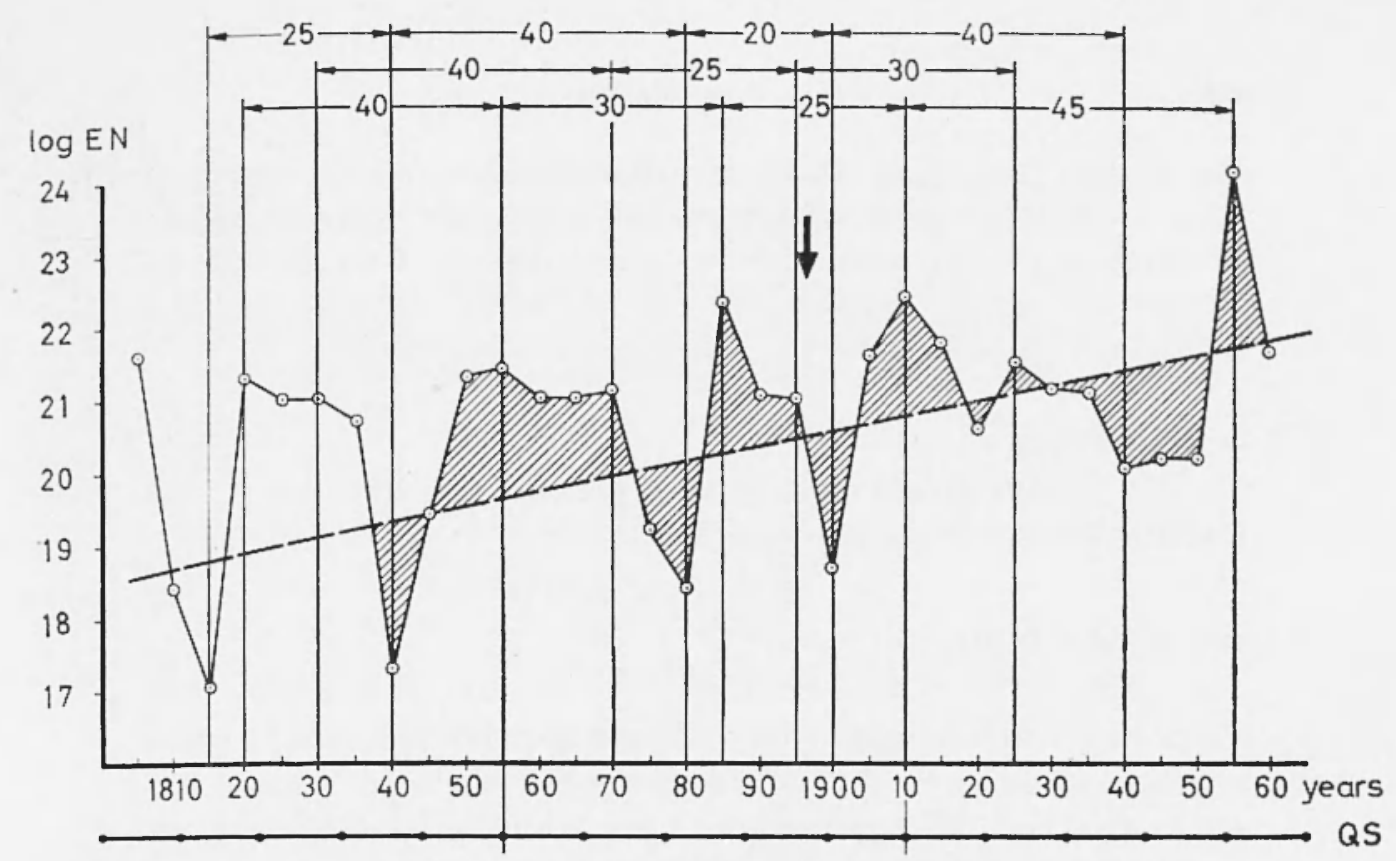

Fig. 1 - Energy variation during 160 years.

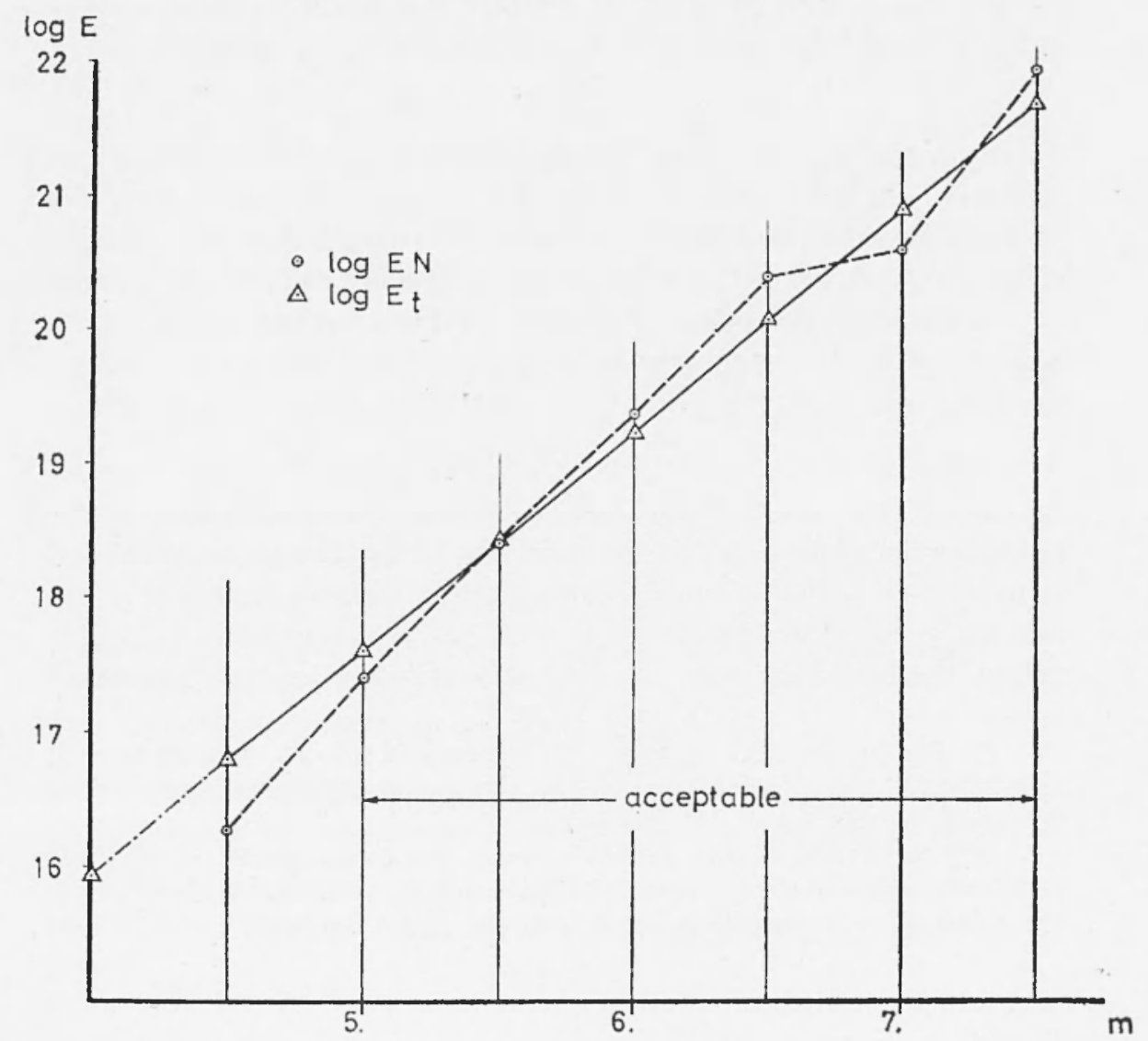

Fig. 2 - Differences between $E N, E_{t}$ values. 
The average from $a), b$ ), c) is approximately $33=3 \cdot n$; the interval $f$ ) is $55=5 \cdot n$; the interval between minima is 110 , double the preceeding. The evolution is pulsative and the graph suggests a certain relation between the energy variation and that of the $Q S$, although this does not mean that it suggests any specific causal relationship.

\section{Total energy $E_{t}$.}

The linear regression which, as a primary approximation $\left({ }^{*}\right)$ was obtained for the whole area (see Ref. $c$ ), is

combining with [1]

$$
\log N=c-m
$$

$$
N E=10^{A}+B \cdot m
$$

which expresses the total energy released per year for each group of a half $m$, and also one half of the energy released in an interval of a whole unity $m$. In agreement with the reasoning of Gutenberg and Richter (1954), it is acceptable, in our case, to take 2.NE as the variation of energy with respect to the unified magnitude. Once the integration is made and the decimal logarithms taken, [3] becomes

$$
\log E_{t}=c+3.511+1.65 m
$$

which proportions the annual energy released up to a magnitude $m$. As results obtained from [4], from $m=5 t_{0} m=7.5$, are acceptable by steps of a half $m$. The error from the leaving out of the constant of integration is smaller than that of grouping $m$ by steps of a half unity.

At the same time that regression [2] was obtained, the expectant (**) in function of the expectancy was defined by $\log N=e_{m}+1-m+$ $\log S ; e_{m}$ being the mean expectancy and $S$ the surface. So, we get

$$
c=e_{m}+1+\log S
$$

Then, the values of the mean expectancy were tabulated by $10^{5}$ $s q \mathrm{~km}$ for the whole area and for every one of the 22 regions established in it, as well as the amount of corresponding surfaces expressed in the said unity; thus the preparation of Table III, which includes the $\log E_{t}$ values, has been very easy. As the regional values are only approxim-

$\left({ }^{*}\right)$ For $M$, from 2.5 up to 6.5 , five years and into the area $36^{\circ}-41^{\circ} \mathrm{N}$, $118^{\circ}-125^{\circ} \mathrm{W}$, Niazi (1964) presents a polinomial adjustment best fitting the linear for the $\log N, M$, regression.

(**) Expectant is the probable mean frequency which is expected in a zone whose surface is evaluated in arbitrary unities. Expectancy is the value of $m$ by which $N=10$ is verified (see Ref. $c$ ). 
ative and defective, the sum of the energies is lower than that directly obtained for the whole area, in each group of magnitude.

Table III - Regional $E_{t}$ values.

\begin{tabular}{|c|c|c|c|c|c|c|c|c|c|}
\hline Reg & $\begin{array}{l}\mathrm{m}=4.5 \\
\mathrm{E} \times 10^{15}\end{array}$ & $\begin{array}{l}m=5.0 \\
E \times 10^{18}\end{array}$ & $\begin{array}{l}m=5.5 \\
E \times 10^{12}\end{array}$ & $\begin{array}{l}m=6.0 \\
E \times 10^{18}\end{array}$ & $\begin{array}{l}\mathrm{m}=6.5 \\
\mathrm{E} \times \mathbf{1}^{\mathbf{1 0}}\end{array}$ & $\begin{array}{l}m=7.0 \\
E \times 10^{20}\end{array}$ & $\begin{array}{l}m=7.5 \\
E \times 10^{21}\end{array}$ & $\begin{array}{l}1801-1960 \\
\text { Maxmal }\end{array}$ & $\mathrm{m}$ \\
\hline 1 & 0.52 & 0.35 & 0.23 & 0.15 & 0.10 & 0.07 & 0.05 & $10.15 \times 10^{18}$ & 6.0 \\
\hline 2 & 0.52 & 0.35 & 0.23 & 0.15 & 0.10 & 0.07 & 0.05 & $0.15 \times 10^{18}$ & 6.0 \\
\hline 3 & 0.78 & 0.52 & 0.35 & 0.23 & 0.15 & 0.10 & 0.07 & $0.15 \times 10^{18}$ & 6.5 \\
\hline 4 & 7.16 & 4.79 & 3.20 & 2.14 & 1.43 & 0.96 & 0.64 & $2.14 \times 10^{18}$ & 6.0 \\
\hline 5 & 0.09 & 0.06 & 0.04 & 0.03 & 0.02 & 0.01 & 0.00 & $0.03 \times 10^{18}$ & 6.0 \\
\hline 6 & 0.26 & 0.17 & 0.12 & 0.08 & 0.05 & 0.03 & 0.02 & $0.05 \times 10^{10}$ & 6.5 \\
\hline 7 & 1.04 & 0.69 & 0.46 & 0.31 & 0.21 & 0.14 & 0.09 & $0.31 \times 10^{18}$ & 6.0 \\
\hline 8 & 0.03 & 0.02 & 0.01 & 0.00 & & & & $0.08 \times 10^{18}$ & 6.0 \\
\hline 9 & 0.78 & 0.52 & 0.35 & 0.23 & 0.15 & 0.10 & 0.07 & $0.15 \times 10^{18}$ & 6.5 \\
\hline 10 & 5.09 & 3.41 & 2.23 & 1.52 & 1.02 & 0.68 & 0.45 & $1.02 \times 10^{19}$ & 6.5 \\
\hline 11 & 4.97 & 3.32 & 2.22 & 1.48 & 0.99 & 0.66 & 0.44 & $0.99 \times 10^{19}$ & 6.5 \\
\hline 12 & 0.78 & 0.52 & 0.35 & 0.23 & 0.15 & 0.10 & 0.07 & $0.15 \times 10^{19}$ & 6.5 \\
\hline 13 & 1.55 & 1.04 & 0.69 & 0.46 & 0.31 & 0.21 & 0.14 & $0.46 \times 10^{18}$ & 6.0 \\
\hline 14 & 2.50 & 1.67 & 1.12 & 0.75 & 0.50 & 0.33 & 0.22 & $0.75 \times 10^{18}$ & 6.0 \\
\hline 15 & 12.10 & 8.09 & 5.41 & 3.62 & 2.42 & 1.62 & 1.08 & $1.08 \times 10^{21}$ & 7.5 \\
\hline 16 & 11.83 & 7.89 & 5.27 & 3.52 & 0.56 & 0.16 & 0.11 & $3.52 \times 10^{18}$ & 6.0 \\
\hline 17 & 0.26 & 0.17 & 0.12 & 0.08 & 0.05 & 0.03 & 0.02 & $0.12 \times 10^{17}$ & 5.5 \\
\hline 18 & 0.52 & 0.35 & 0.23 & 0.16 & 0.10 & 0.07 & 0.05 & $0.10 \times 10^{19}$ & 6.5 \\
\hline 19 & 1.55 & 1.04 & 0.69 & 0.46 & 0.31 & 0.21 & 0.14 & $0.21 \times 10^{20}$ & 7.0 \\
\hline 20 & 4.58 & 3.06 & 2.05 & 1.37 & 0.91 & 0.61 & 0.41 & $1.37 \times 10^{18}$ & 6.0 \\
\hline 21 & 1.55 & 1.04 & 0.69 & 0.46 & 0.31 & 0.21 & 0.14 & $0.46 \times 10^{18}$ & 6.0 \\
\hline 22 & 0.23 & 0.16 & 0.10 & 0.07 & 0.05 & 0.03 & 0.02 & $0.03 \times 10^{20}$ & 7.0 \\
\hline $\mathrm{m}$ & 58.59 & 39.23 & 26.16 & 17.50 & 9.89 & 6.40 & 4.28 & & \\
\hline ea & 61.40 & 41.02 & 27.42 & 18.32 & 12.25 & 8.18 & 5.47 & $5.47 \times 10^{21}$ & 7.5 \\
\hline
\end{tabular}

The results $\log E N$ and the differences with $\log E_{\ell}$ appear at the end of Table II; Fig. 2 confirms that it is acceptable to replace one by 
the other, from $m=5-7.5$. The quadratic mean error is lower than $3 / t$ of the one almitted by $m$. If we accept a higher error and also the extrapolation up to $t$ and 8 , they are

$$
\frac{m}{E_{t}} \frac{4-5 ?}{0.005} \frac{5-6}{0.2} \frac{6-7}{8} \frac{7-8 ?}{320} \times 10^{20} \mathrm{erg}
$$

Ciphers that are useful as an orientation in the mean amount of the anmual energy released in the whole area.

\section{Energy and frequency.}

For the instrumental period, from 1901 to 1960 (see Ref. $c$ ), an almost constant dephasage, close to two years, was noticed, between the maximal relative frequency and the minimal solar activity. Table IV includes the ammal values of the encrgy released and Figr. 3 compares the variations of the logarithm of the energy with the frequency. In this figure a full line to $\log E N$ and a discontinuous line to $N$ are drawn. As was supposed, the figure shows a similarity between both 'urves, but within a wide generality. The noticable and coinciding maxima of 1909 and 1951 establish different intervals between the particular maxima corresponding to each one of the curves, whose avelages are 8.4 and 7 years. The pairs of intervals $N, 9$ and $\log E, \tau$ occur three times. We can see an irregular displacement of the respective maxima and also several points in remarkable disagreement, which are indicated by arrows. In them, the maximal energy released not only does not coincide with a maximal frequency, but at times it is maximal energy versus minimal frequency and vice versa. Perhaps, the two most noticeable singular points are 1942 and 1954 ; the first shows a notable maximum of $N$ versus a low value for $E$, and the second, on the contrary, an extreme value for $E$ versus another scanty one for $N$. With regard to the $Q S$ line, there is a coincidence of $E, N$, minima with $Q S$, only in 1921. For 1910, 1932 and 1943 it can be verified that $Q S$ is equidistant from $E, N$, both maxima, though the order is not the same for 1932 as for the other two years.

We can not draw any firm conclusion from this analysis, although a pulsation of several short periods confused with another longer one was perceived and it is not possible to affirm that the logarithm of energy is proportional to the frequency, in the studied area. 


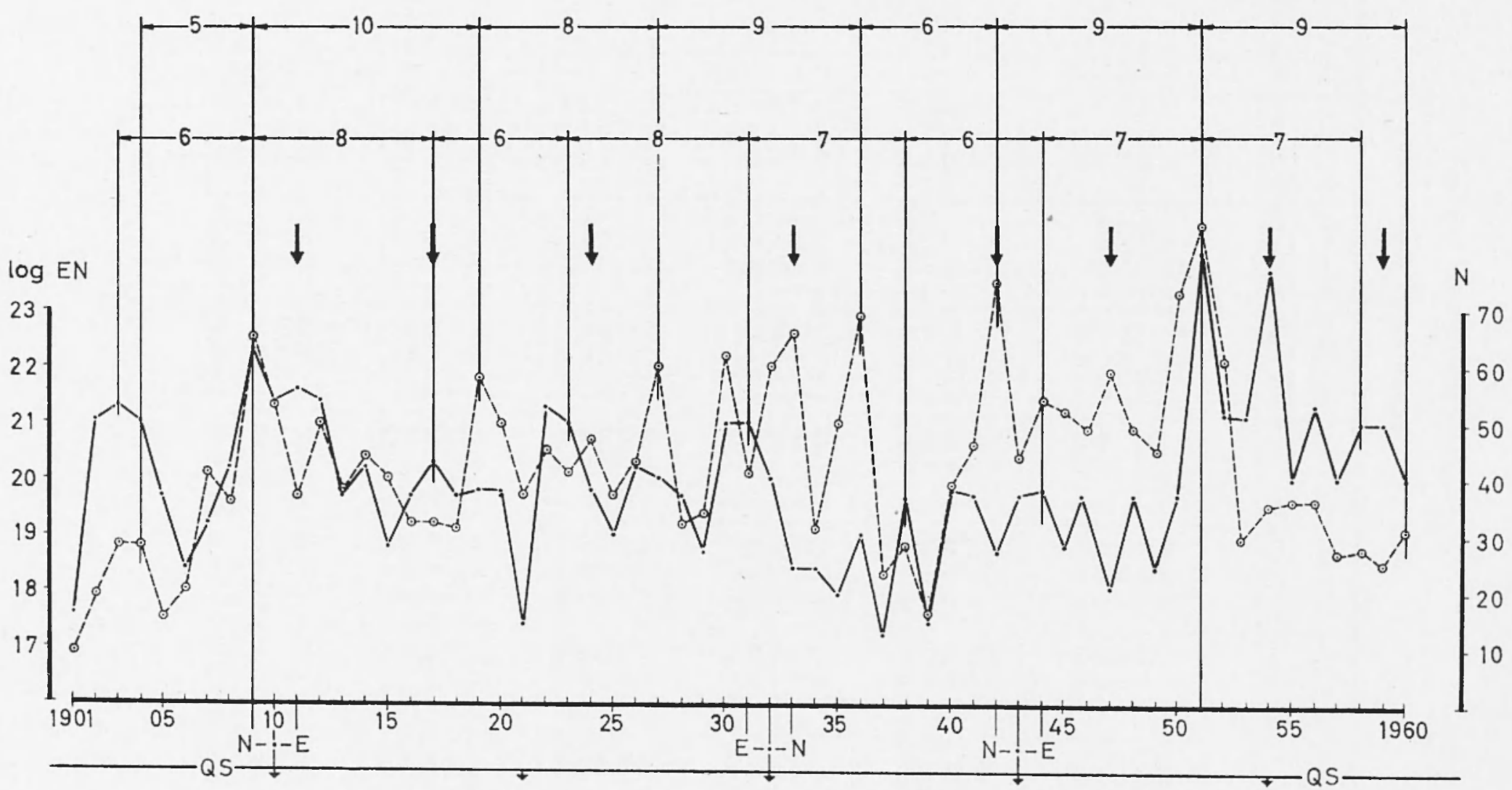

Fig. 3 - Comparison between energy and frequency. 
Table IV. - Annual energy (1901-1960)

\begin{tabular}{|c|c|c|c|c|c|c|c|c|c|c|c|c|c|c|}
\hline \multirow{2}{*}{ Years } & \multicolumn{2}{|c|}{$\mathrm{m}=4.5$} & \multicolumn{2}{|c|}{$\mathrm{m}=5.0$} & \multicolumn{2}{|c|}{$\mathrm{m}=5.5$} & \multicolumn{2}{|c|}{$\mathrm{m}=6.0$} & \multicolumn{2}{|c|}{$\mathrm{m}=6.5$} & \multicolumn{2}{|c|}{$\mathrm{m}=7.0$} & $\mathrm{~m}=7.5$ & \multirow{2}{*}{$\begin{array}{l}\text { Total } \\
\log \mathrm{E}\end{array}$} \\
\hline & $\mathrm{N}$ & $E \times 10^{17}$ & $\mathrm{~N}$ & $E \times 10^{18}$ & $\mathrm{~N}$ & $E \times 10^{10}$ & $\mathrm{~N}$ & $E \times 10^{20}$ & $\mathrm{~N}$ & $E \times 10^{22}$ & $\mathrm{~N}$ & $E \times 10^{23}$ & $\mathrm{~N} \mid \mathrm{E} \times 1 \mathrm{G}^{24}$ & \\
\hline $\begin{array}{r}1901 \\
2 \\
3 \\
4 \\
5\end{array}$ & $\begin{array}{l}2 \\
4 \\
7 \\
2\end{array}$ & $\begin{array}{l}0.10 \\
0.21 \\
0.36 \\
0.10\end{array}$ & $\begin{array}{l}4 \\
2 \\
5 \\
4 \\
1\end{array}$ & $\mid \begin{array}{l}0.44 \\
0.22 \\
0.55 \\
0.44 \\
0.11\end{array}$ & $\begin{array}{l}2 \\
1\end{array}$ & $\begin{array}{l}0.23 \\
0.46 \\
0.23\end{array}$ & 1 & $\begin{array}{l}0.49 \\
0.49\end{array}$ & $\begin{array}{l}1 \\
2 \\
1\end{array}$ & $\begin{array}{l}0.10 \\
0.21 \\
0.10\end{array}$ & & & & $\begin{array}{l}17.64 \\
21.02 \\
21.33 \\
21.02 \\
19.71\end{array}$ \\
\hline $\begin{array}{r}6 \\
7 \\
8 \\
9 \\
10\end{array}$ & \begin{tabular}{r|}
4 \\
8 \\
2 \\
4 \\
14
\end{tabular} & $\begin{array}{l}0.21 \\
0.42 \\
0.10 \\
0.21 \\
0.73\end{array}$ & $\begin{array}{r}1 \\
3 \\
4 \\
14 \\
10\end{array}$ & $\begin{array}{l}0.11 \\
0.33 \\
0.44 \\
1.54 \\
1.10\end{array}$ & $\begin{array}{l}1 \\
6 \\
4 \\
6 \\
4\end{array}$ & $\begin{array}{l}0.23 \\
1.39 \\
0.93 \\
1.39 \\
0.93\end{array}$ & $\begin{array}{l}3 \\
4 \\
3\end{array}$ & $\begin{array}{l}1.47 \\
1.96 \\
1.47\end{array}$ & $\begin{array}{l}2 \\
2\end{array}$ & $\begin{array}{l}0.21 \\
0.21\end{array}$ & 1 & 0.22 & & $\begin{array}{l}18.39 \\
19.16 \\
20.17 \\
22.38 \\
21.35\end{array}$ \\
\hline $\begin{array}{l}11 \\
12 \\
13 \\
14 \\
15\end{array}$ & $\begin{array}{r}9 \\
13 \\
8 \\
14 \\
8\end{array}$ & $\begin{array}{l}0.47 \\
0.68 \\
0.42 \\
0.73 \\
0.42\end{array}$ & $\begin{array}{r}5 \\
6 \\
6 \\
5 \\
15\end{array}$ & $\begin{array}{l}0.55 \\
0.66 \\
0.66 \\
0.55 \\
1.65\end{array}$ & $\begin{array}{l}7 \\
6 \\
9 \\
3 \\
2\end{array}$ & $\begin{array}{l}1.62 \\
1.39 \\
2.09 \\
0.70 \\
0.46\end{array}$ & $\begin{array}{l}1 \\
3 \\
1 \\
4\end{array}$ & $\begin{array}{l}0.49 \\
1.47 \\
0.49 \\
1.96\end{array}$ & $\begin{array}{l}4 \\
2\end{array}$ & $\begin{array}{l}0.41 \\
0.21\end{array}$ & & & & $\begin{array}{l}21.62 \\
21.35 \\
19.84 \\
20.31 \\
18.82\end{array}$ \\
\hline $\begin{array}{l}16 \\
17 \\
18 \\
19 \\
20\end{array}$ & $\begin{array}{r}6 \\
9 \\
9 \\
11 \\
12\end{array}$ & $\begin{array}{l}0.31 \\
0.47 \\
0.47 \\
0.57 \\
0.62\end{array}$ & $\begin{array}{r}9 \\
6 \\
4 \\
8 \\
12\end{array}$ & $\begin{array}{l}0.99 \\
0.66 \\
0.44 \\
0.88 \\
1.32\end{array}$ & $\begin{array}{l}1 \\
4 \\
1 \\
6 \\
4\end{array}$ & $\begin{array}{l}0.23 \\
0.93 \\
0.23 \\
1.39 \\
0.93\end{array}$ & $\begin{array}{l}1 \\
4 \\
1 \\
1 \\
1\end{array}$ & $\begin{array}{l}0.49 \\
1.96 \\
0.49 \\
0.49 \\
0.49\end{array}$ & & & & & & $\begin{array}{l}19.72 \\
20.31 \\
19.71 \\
19.81 \\
19.78\end{array}$ \\
\hline $\begin{array}{l}21 \\
22 \\
23 \\
24 \\
25\end{array}$ & $\begin{array}{r}6 \\
14 \\
13 \\
7 \\
3\end{array}$ & $\begin{array}{l}0.31 \\
0.73 \\
0.68 \\
0.36 \\
0.16\end{array}$ & $\begin{array}{l}4 \\
6 \\
6 \\
3 \\
3\end{array}$ & \begin{tabular}{|l|}
0.44 \\
0.66 \\
0.66 \\
0.33 \\
0.33
\end{tabular} & $\begin{array}{l}1 \\
1 \\
3 \\
4 \\
4\end{array}$ & $\begin{array}{l}0.23 \\
0.23 \\
0.70 \\
0.93 \\
0.93\end{array}$ & $\begin{array}{l}2 \\
1 \\
1\end{array}$ & $\begin{array}{l}0.98 \\
0.49 \\
0.49\end{array}$ & $\begin{array}{l}2 \\
1\end{array}$ & $\begin{array}{l}0.21 \\
0.10\end{array}$ & & & & $\begin{array}{l}17.44 \\
21.34 \\
21.03 \\
19.77 \\
18.98\end{array}$ \\
\hline $\begin{array}{l}26 \\
27 \\
28 \\
29 \\
30\end{array}$ & $\begin{array}{r}7 \\
23 \\
9 \\
13 \\
17\end{array}$ & $\begin{array}{l}0.36 \\
1.20 \\
0.47 \\
0.68 \\
0.88\end{array}$ & $\begin{array}{r}7 \\
6 \\
4 \\
10 \\
12\end{array}$ & $\begin{array}{l}0.77 \\
0.66 \\
0.44 \\
1.10 \\
1.32\end{array}$ & $\begin{array}{l}1 \\
2 \\
3\end{array}$ & $\begin{array}{l}0.93 \\
0.23 \\
0.46 \\
0.70\end{array}$ & $\begin{array}{l}3 \\
2 \\
1\end{array}$ & $\begin{array}{l}1.47 \\
0.98 \\
0.49 \\
\\
0.49\end{array}$ & 1 & 0.10 & & & & $\begin{array}{l}20.17 \\
19.99 \\
19.71 \\
18.76 \\
21.03\end{array}$ \\
\hline
\end{tabular}


(Tab. IV, cont.)

\begin{tabular}{|c|c|c|c|c|c|c|c|c|c|c|c|c|c|c|c|}
\hline \multirow{2}{*}{ Years } & \multicolumn{2}{|c|}{$\mathrm{m}=3.5$} & \multicolumn{2}{|c|}{$\mathrm{m}=5.0$} & \multicolumn{2}{|c|}{$\mathrm{m}=5.5$} & \multicolumn{2}{|c|}{$\mathrm{m}=6.0$} & \multicolumn{2}{|c|}{$\mathrm{m}=6.5$} & \multicolumn{2}{|c|}{$\mathrm{m}=7.0$} & \multicolumn{2}{|c|}{$\mathrm{m}=7.5$} & \multirow{2}{*}{$\begin{array}{l}\text { Total } \\
\log \mathrm{E}\end{array}$} \\
\hline & $\mathrm{N}$ & $E \times 10^{17}$ & $\mathrm{~N}$ & $E \times 10^{18}$ & $\mathrm{~N}$ & $E \times 10^{19}$ & $N$ & $E \times 10^{20}$ & $\mathrm{~N}$ & $E \times 10^{22}$ & $\mathrm{~N}$ & $E \times 10^{23}$ & $\mathrm{~N}$ & $E \times 10^{24}$ & \\
\hline $\begin{array}{r}1931 \\
32 \\
33 \\
34 \\
35\end{array}$ & $\begin{array}{r}9 \\
15 \\
5 \\
6 \\
7\end{array}$ & $\begin{array}{l}0.47 \\
0.78 \\
0.26 \\
0.31 \\
0.36\end{array}$ & $\begin{array}{l}7 \\
3 \\
2 \\
1 \\
7\end{array}$ & $\begin{array}{l}0.77 \\
0.33 \\
0.22 \\
0.11 \\
0.77\end{array}$ & $\begin{array}{l}1 \\
1 \\
1\end{array}$ & $\begin{array}{l}0.23 \\
0.23 \\
0.23\end{array}$ & $\begin{array}{l}1 \\
1 \\
1\end{array}$ & $\begin{array}{l}0.49 \\
0.49 \\
0.49\end{array}$ & 1 & 0.10 & & & & & $\begin{array}{l}21.02 \\
19.69 \\
19.71 \\
18.39 \\
17.91\end{array}$ \\
\hline $\begin{array}{l}36 \\
37 \\
38 \\
39 \\
40\end{array}$ & $\begin{array}{r}10 \\
10 \\
1 \\
2 \\
5\end{array}$ & $\begin{array}{l}0.52 \\
0.52 \\
0.05 \\
0.10 \\
0.26\end{array}$ & $\begin{array}{l}4 \\
1 \\
2 \\
2 \\
3\end{array}$ & $=\begin{array}{l}0.44 \\
0.11 \\
0.22 \\
0.22 \\
0.33\end{array}$ & $\begin{array}{l}4 \\
1 \\
3\end{array}$ & $\begin{array}{l}0.93 \\
0.23 \\
0.69\end{array}$ & 1 & $\begin{array}{l}0.49 \\
0.49\end{array}$ & & & & & & & $\begin{array}{l}18.99 \\
17.21 \\
19.71 \\
17.36 \\
19.75\end{array}$ \\
\hline $\begin{array}{l}41 \\
42 \\
43 \\
44 \\
45\end{array}$ & $\begin{array}{r}10 \\
15 \\
9 \\
7 \\
7\end{array}$ & $\begin{array}{l}0.52 \\
0.78 \\
0.47 \\
0.36 \\
0.36\end{array}$ & $\begin{array}{l}5 \\
4 \\
8 \\
5 \\
1\end{array}$ & $\begin{array}{l}0.55 \\
0.44 \\
0.88 \\
0.55 \\
0.11\end{array}$ & $\begin{array}{l}2 \\
2 \\
1 \\
3 \\
2\end{array}$ & $\begin{array}{l}0.46 \\
0.46 \\
0.23 \\
0.70 \\
0.46\end{array}$ & $\begin{array}{l}1 \\
1\end{array}$ & $\begin{array}{l}0.49 \\
0.49 \\
0.49\end{array}$ & & & & & & & $\begin{array}{l}19.73 \\
18.71 \\
19.72 \\
19.75 \\
18.66\end{array}$ \\
\hline $\begin{array}{l}46 \\
47 \\
48 \\
49 \\
50\end{array}$ & $\begin{array}{r}12 \\
8 \\
5 \\
9 \\
5\end{array}$ & \begin{tabular}{|l|}
0.62 \\
0.42 \\
0.26 \\
0.47 \\
0.26
\end{tabular} & $\begin{array}{l}7 \\
8 \\
1 \\
4 \\
5\end{array}$ & $\begin{array}{l}0.77 \\
0.88 \\
0.11 \\
0.44 \\
0.55\end{array}$ & $\begin{array}{l}2 \\
1 \\
1 \\
5\end{array}$ & $\begin{array}{l}0.46 \\
0.23 \\
0.23 \\
1.16\end{array}$ & 1 & $\begin{array}{l}0.49 \\
0.49 \\
0.49\end{array}$ & & & & & & & $\begin{array}{l}19.74 \\
17.96 \\
19.71 \\
18.44 \\
19.71\end{array}$ \\
\hline $\begin{array}{l}51 \\
52 \\
53 \\
54 \\
55\end{array}$ & $\begin{array}{r}18 \\
9 \\
9 \\
4 \\
8\end{array}$ & $\begin{array}{l}0.93 \\
0.47 \\
0.47 \\
0.21 \\
0.42\end{array}$ & $\begin{array}{l}5 \\
5 \\
1 \\
4 \\
2\end{array}$ & $\begin{array}{l}0.55 \\
0.55 \\
0.11 \\
0.44 \\
0.22\end{array}$ & \begin{tabular}{l|l}
2 \\
1 \\
1 \\
1 \\
1
\end{tabular} & $\begin{array}{l}0.46 \\
0.23 \\
0.23 \\
0.23 \\
0.23\end{array}$ & $\begin{array}{l}3 \\
3 \\
3 \\
2\end{array}$ & $\begin{array}{l}1.47 \\
1.47 \\
1.47 \\
0.98\end{array}$ & $\begin{array}{l}1 \\
1\end{array}$ & $\begin{array}{l}0.10 \\
0.10\end{array}$ & l & 0.22 & 2 & 0.93 & $\begin{array}{l}23.97 \\
21.06 \\
21.06 \\
23.68 \\
20.00\end{array}$ \\
\hline $\begin{array}{l}56 \\
57 \\
58 \\
59 \\
60\end{array}$ & $\begin{array}{l}9 \\
3 \\
5 \\
6\end{array}$ & \begin{tabular}{|l|}
0.47 \\
0.16 \\
\\
0.26 \\
0.31
\end{tabular} & $\begin{array}{l}4 \\
4 \\
9 \\
3 \\
6\end{array}$ & $\begin{array}{l}0.44 \\
0.44 \\
0.99 \\
0.33 \\
0.66\end{array}$ & $\begin{array}{l}4 \\
1 \\
5 \\
1 \\
1\end{array}$ & $\begin{array}{l}0.93 \\
0.23 \\
1.16 \\
0.23 \\
0.23\end{array}$ & $\begin{array}{l}2 \\
2\end{array}$ & $\begin{array}{l}0.98 \\
\\
0.98 \\
0.98\end{array}$ & $\begin{array}{l}2 \\
1 \\
1\end{array}$ & $\begin{array}{l}0.21 \\
0.10 \\
0.10\end{array}$ & & & & & $\begin{array}{l}21.32 \\
20.00 \\
21.00 \\
21.00 \\
20.00\end{array}$ \\
\hline
\end{tabular}


III. - SEISHIC: HI:X.

\section{S'rismicity and tectomic fluat.}

As Bath (195.3) reaffirms, seismicity is defined as the total energy release by unity of area and unity of time, and the elastic strain released, in a given instant, is proportional to the square root of the strain energy released, in agreement with St Amand (1956) who proposes the term "tectonic flux", used for the first time by Benioff. Both, seismic energy and strain energy released at the focus are related by a parameter which, though dependient of the magnitude, we can accept $q=1$; so, practically, $E=J$. In the present paper, the decimal logarithm of the tectonic lux flux is used as follows

$$
\varnothing=\log F=0.5 \log E-1.097
$$

which is deduced from

$$
F=\frac{(\Sigma E)^{1 / 2}}{5 \times 2.5}
$$

$F$ being the tectonic flux and $E=J$ the total energy released into a quadricle of the area during a Iustre $\left(^{*}\right)$. The values $E, \varnothing$ are quoted in Table $V$ only for the earthquakes of the period 1901-1960 with their acceptably located epicenter. Fig. 4 shows the 12 corresponding graphs in which simple symbols are used for $\varnothing$ : lower than $6.5,8,9.5$ and 11 . From an auxiliary table, to 4 lapses of 15 years, values of $\varnothing$ have been prepared and plotted in the Fig. 5 graphs. Fig. 6 is drawn with the mean values, $\varnothing$, of the seismic: activity regarding the whole instrumental period; this figure resembles Rey Pastor's sketch (1927), which only included clata up to the year $1925\left(^{* *}\right)$.

\section{Seismic nucleii.}

In Fig. 6 it is possible to see that the following more important nucleii are predomimant:

- Central Pyrenees,

- low basin of Segura river,

- Southern Sierra Nevala mountain,

(*) The area was divided into 540 quadricies, of $0.5 \times 0.5$ greographic decrees, of approximately $2,500 \mathrm{sq} \mathrm{km}$ (see Ref. c).

$\left({ }^{* *}\right)$ Future references to this sketch will be briefly noted $R I$ ' 

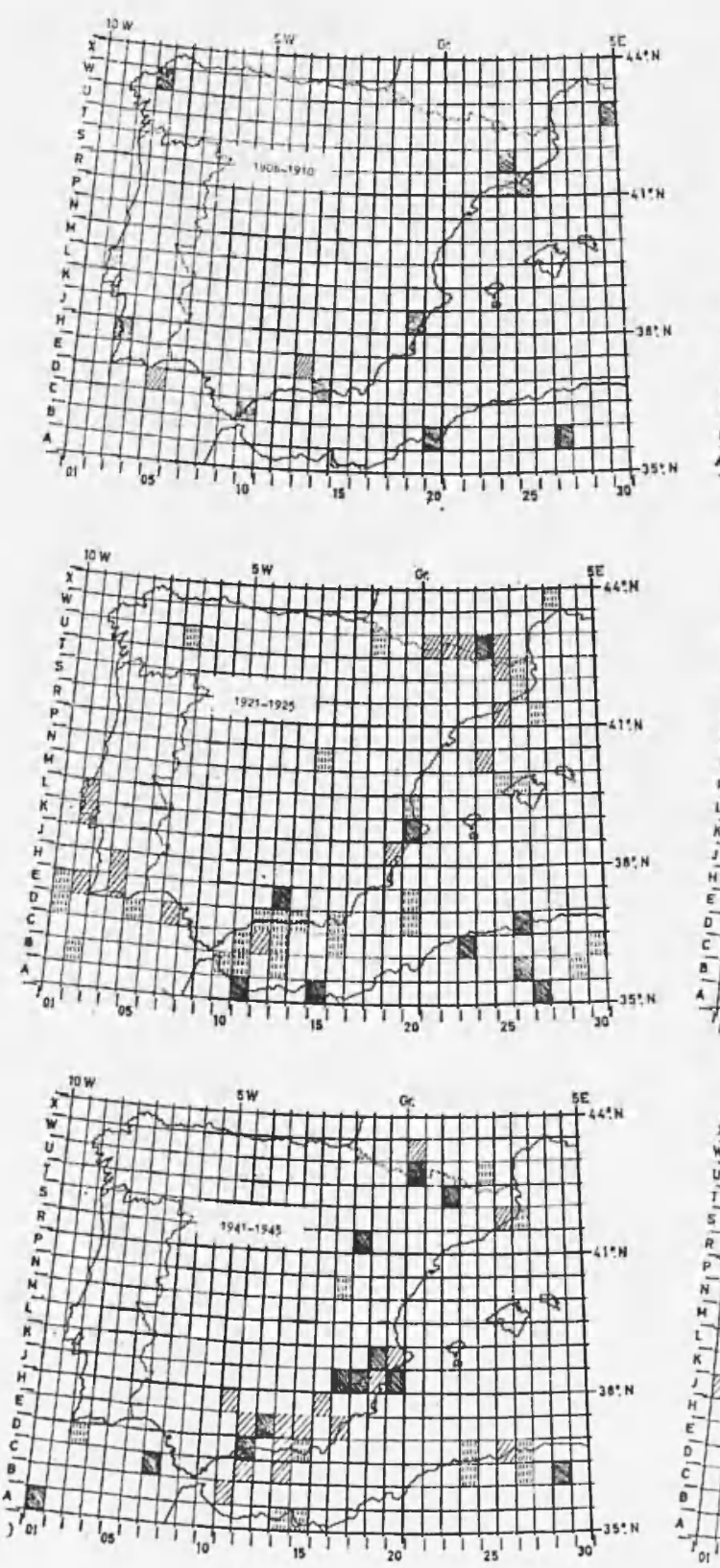

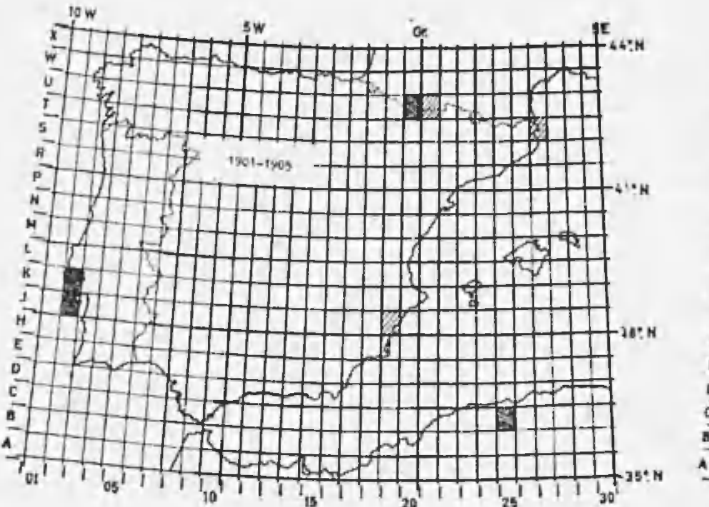

(10\%

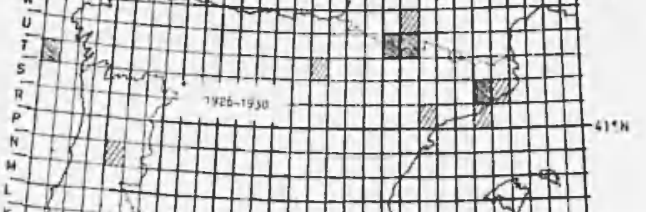

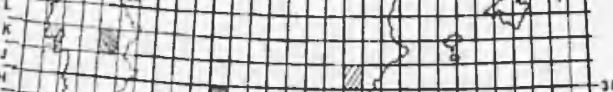
\begin{tabular}{l|l|l|}
\hline & \\
\hline
\end{tabular} c

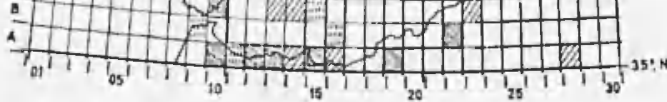

tow (1) : :

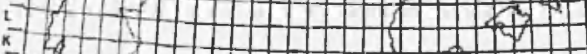
-

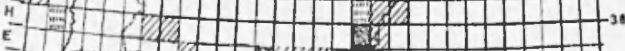
: :

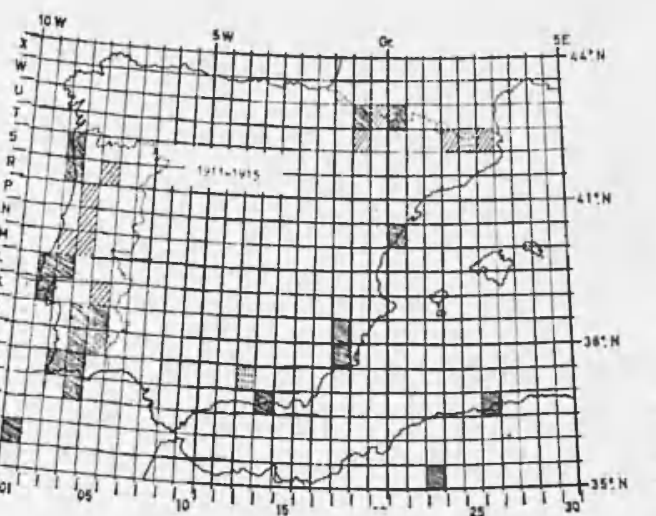

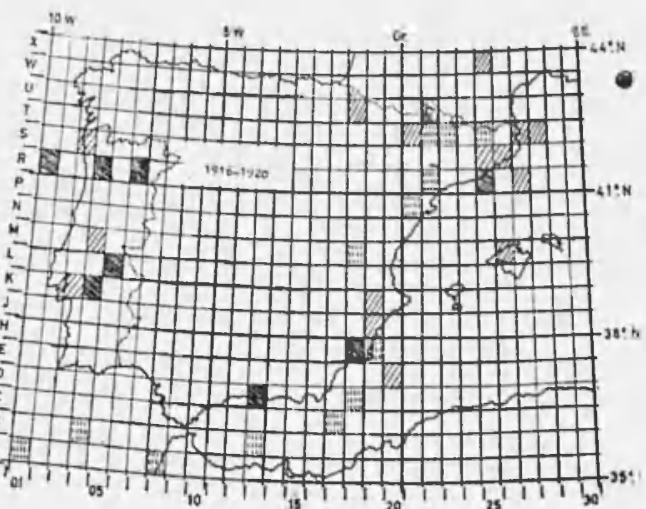

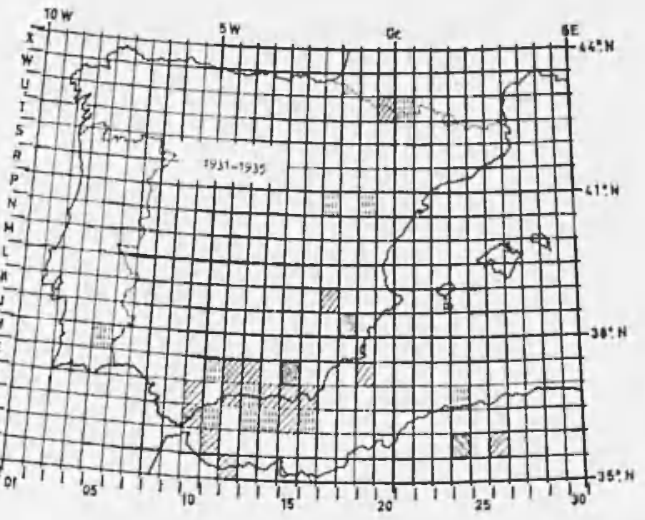
(jow i 年 洪 i

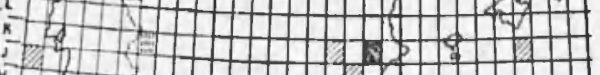

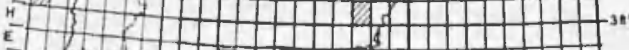

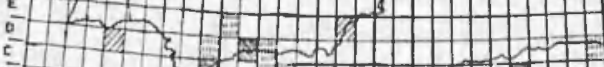
:

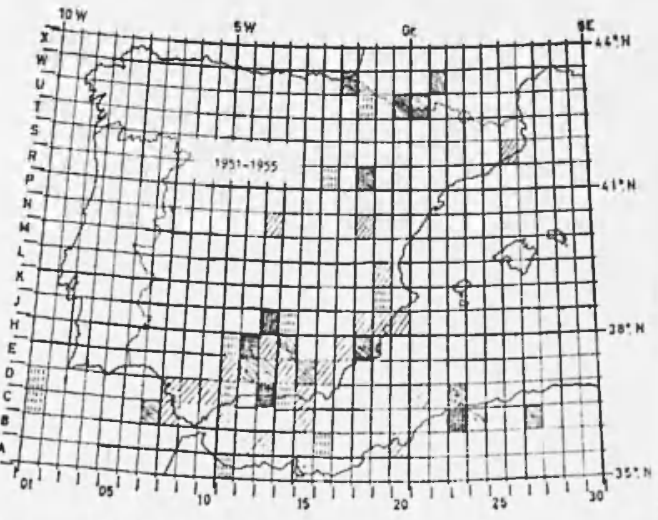
(1)

Fig. 4 - Flux by groups of 5 years. 

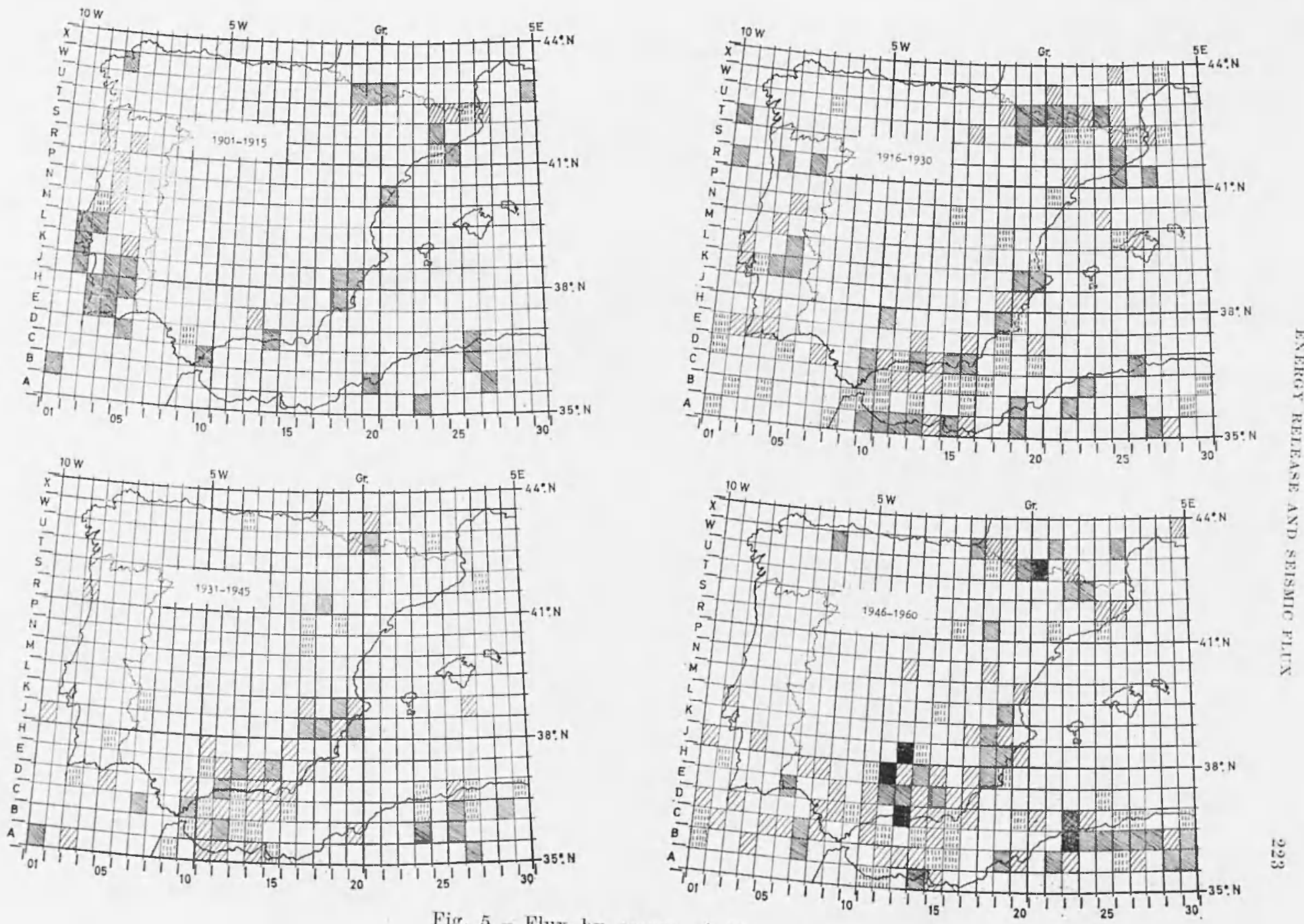

Fig. 5 - Flux by groups of 15 years. 


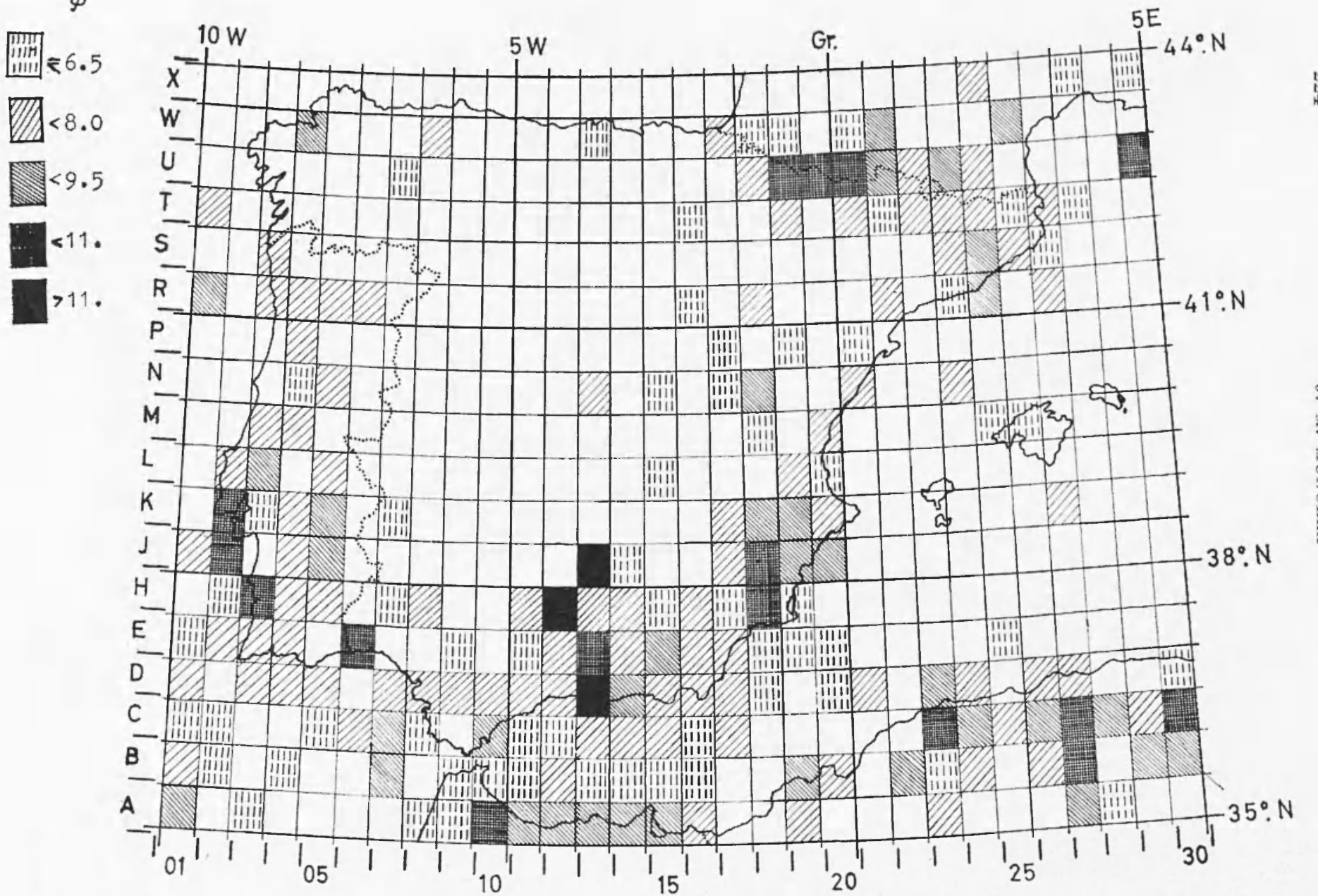

Fig. 6 - Annual flux average (1901-1960). 
- Algerian zone, within which the two most destructive earthquakes of the present century have been located (No 1055, No 3068, from Ref. b),

- an area that seems to have decreased in activity which was stronger in the past historical period, located in the Tajo estuary and towards its immediate $S$ and $S E$,

- another area underlining the meridional coasts of Portugal and Seno Gaditano.

An extensive seismic density is also observed in the Alboran sea, with energy releases lower than those corresponding to the focii located close to the African coast from Ceuta to Chafarinas islands. Other less important areas are shown in different places; as occurs between the Mondego river and the Minyo mouth, where remote historical earthquakes are attributed; the Eastern and Western extremes of the Pyrenees; the Catalonian nucleii, from Montseny to the coast; the Gulf of Lyon and several additional zones.

A seismic lagoon is evident at the Ibiza and Formentera island proximities, where there is no occurrence of earthquakes at all, not only between instrumental ones but also for those conjectural or uncertain locations of the historical period. Another interesting feature is the noting of sequences linking the Betican and the Algerian earthquakes (see Ref. $b$ ). We suggest that this point should be studied in the future, and for that purpose it would be necessary to have record of the data from short period portable seismograph equipment to be established at convenient places in Baleares, Ceuta and Melilla; i.e., these would complement the permanent net of Spanish Observatories of Malaga, Almeria, Alicante and Cartuja as well as the Relizane and Alger Algerian seismological stations. The nearest Morocco Observatory is located in the South, too far away for that object (*), and the nearest seismologieal station in the Portuguese territory is that of Lisbon.

\section{Seismic activity map.}

With a basis in the data from the acceptable epicenters plotted on the map of Ref. c) we have prepared the seismic activity map by the following method:

(*) Since 31 Oct, $64 ; 20 \mathrm{~h} 13 \mathrm{~m}$, the Ifrane Observatory has begun operation, $\left(33^{\circ} 31^{\prime} \mathrm{N}, 5^{\circ} 07^{\prime} \mathrm{W}\right)$. 
1st) - for each seismically active quadricle has been computed

$$
\varnothing=\log \frac{(\Sigma H N)}{60 \times 2.5}
$$

where the factors and symbols have the same significance as in [7], but now the amount of years is 60 , and $N$ is the absolute frequency by groups of $1 / 2$ unity of $m$,

2nd) - the value of $\varnothing$ is assigned to the most significant epicenter of the corresponding quadricle, considering it thus the deepest focus (deep, intermediate or shallow shocks) and among them, the one with a higher $E N$ value,

3rd) - with these prior results, the curves of equal activity (for $\varnothing=$ $6,7,8,9)$ has been drawn and representing the hipsometrics, as a progressively intense tonality.

Fig. 7 is a sketch of this map (*) and this is adequate for comparisons with other geotectonic or geophysic maps. The alignments of the epicenters could be utilized as a general reference but keeping in mind that the true epicentral groups or distributions are not reflected by the significant epicenters.

The alignment of the significant epicenters of the Pyrenees coincides with the mountain range from the West to Andorra, where it is divided in three directions; one of them is SW-NE, another incurvs and goes inside the Lyon's Gulf and the third one goes towards Barcelona, in the direction of NW to South.

A full line links the epicenters of the intermediate shocks with which the Guadalquivir Fault is drawn, and also the inter-oceanic bottom between the Atlantic ocean and the Mediterranean sea. The first line is in complete accordance with the information of the surface geological maps and, as we shall see, with the geotectonic ones as well. The second said alignment seems to suggest another fault in the Atlantic ocean as a regression or insertion of the first one; other studies, though not conclusive, such as those made by Martin Romero (1958), suggest a probable breaking direction in the Seno Gaditano oriented from the

(*) We are planning to publish a complete seismic activity map, scale $1: 2.000 .000$ together with a good representation of the regional tectonics of the area, for which some time is needed until the actual information can be obtained from experts in Geotectonics, from the different implicated countries (Spain, France, Algeria, Morocco and Portugal). 


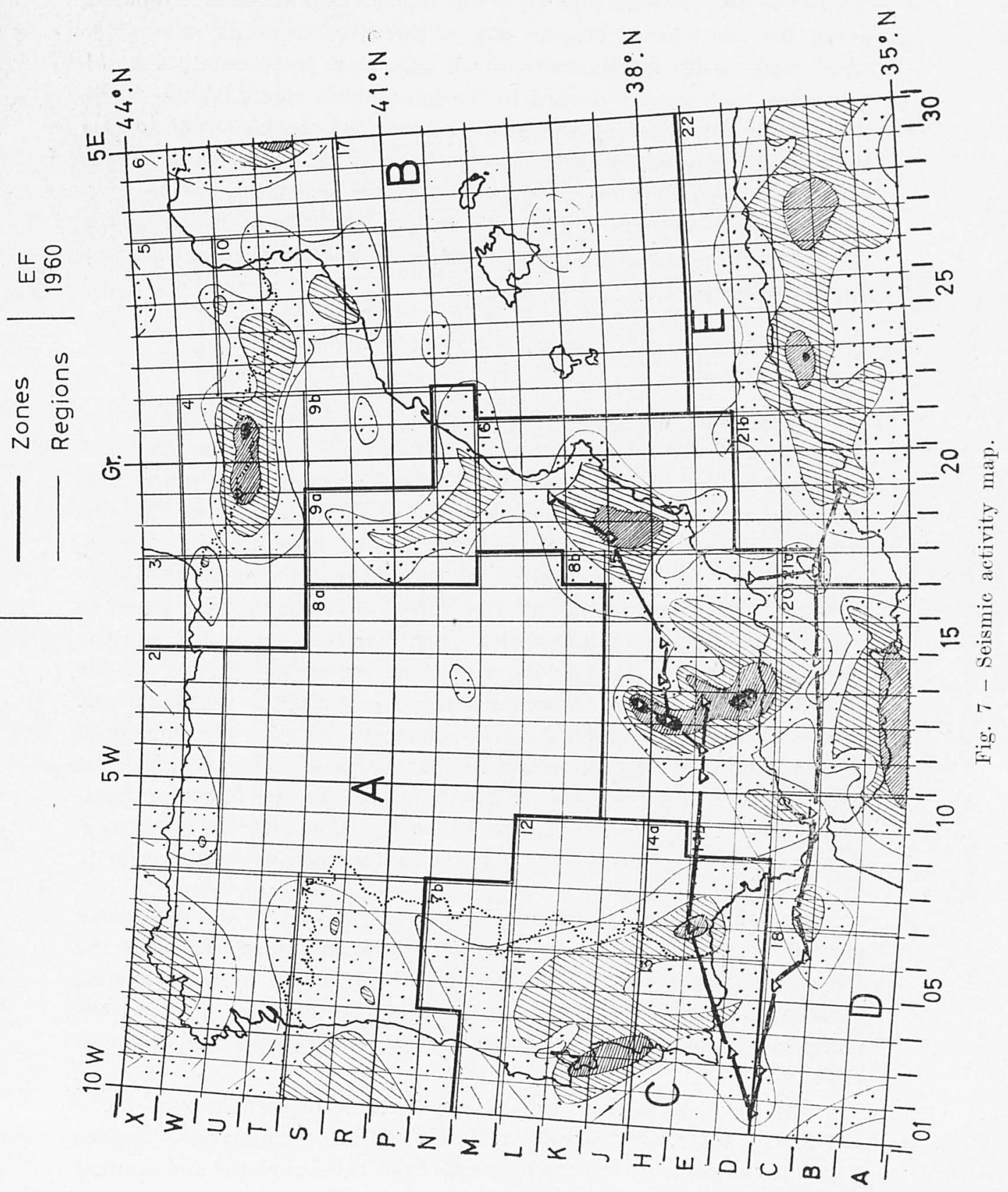


NE to the SW. Specific studies in this region could elucidate. Whether or not the two "foci", on each side of the Gibraltar strait, were in the same fault; other intermediate shock epicenters appeared in the Alboran sea, very clearly aligned to the bathimetric cote $2.000 \mathrm{~m}$, where the oceanic character of the Mediterranean sea begins. Considering the possible marginal links of these last shocks, i.e., by Sierra de Grazalema at W, and by Cabo de Gata, Almanzora and Genil valley, at $\mathrm{E}$ and $\mathrm{NE}$, there appears a half-close with a lenticular form surronding the Sierra Nevada region and in whose roots was located the sole deep focus earthquake.

\section{Seismic zones.}

The division into seismic regions made in Ref. c) tooks into account the density of the epicenters for all the available information that was published in Ref. $b$ ). This permits a control of the graphic representations and also gives an approximate idea of the noticeable seismic differences between the divers parts of the studied area. The seismic activity map gives the opportunity to note these differences with more accuracy. We have established five zones, adjusted in their limits to follow whole half-degree quadricles. Fig. 8 shows these zones and the aforesaid regions as well as the zones and regions established on the $R P$ sketch, which were determined through geological considerations. You can see an acceptable general agreement between the bounds of the zone and of the region, except in a few cases, and also an agreement between the zones belonging to booth maps. In the following parngraphs these two maps are discussed in comparison with the description of zones based on the seismic activity in the recently prepared map.

A. - Central Zone; integrated by the regions $1,2,8$ and the greater part of 7 ; its oriental and meridional bounds are clearly those of the $R P$ sketch; the $\mathrm{N}$ and $\mathrm{W}$ ends are slightly displaced by the widening of Zone C. The Central Zone includes both the Castillian plateaus, the Cantabric coast, Galicia and Northern Portugal, from the Mondego river.

This zone shows four surfaces $\varnothing>7$; three of them corresponding to region 7; the other one appears in the NW corner and a weak nucleus $\varnothing=7$ is embedded in Asturias. Aside from these surfaces and another smaller one in the lower valley of the Jarama river, almost the whole zone is a semi-seismic lagoon. 


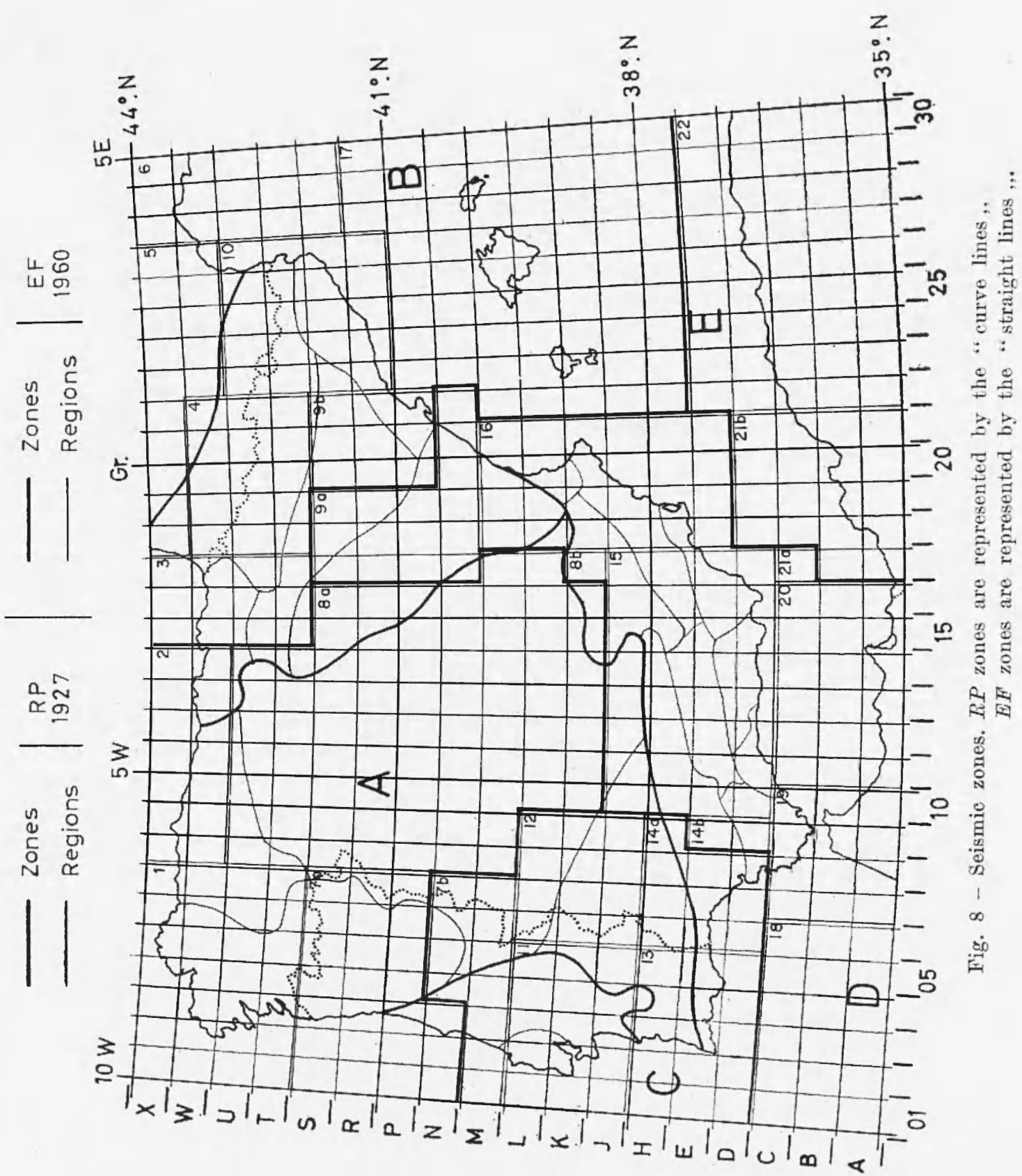


B. - Oriental Zone; includes the regions 3, 4, 5, 6, 10, 17 and almost half of 9 (depression of the Ebro). It coincides with the zone defined by RP, except for the SW (Maestrazgo and Jiloca's valley) which it seems preferable to include in Zone $\mathrm{D}$.

The zone has four surfaces $\varnothing=7-8$. The first towards the NE, is located in the Lyon's Gulf at the edge of the studied area; for which reason it is not se well defined.

With regard to the other three surfaces, the Southern most one is in the Besos and Ilobregat basins; the more important one, in the Central Pyrenees, includes an intermediate shock and reaches $\varnothing=9$, and the smallest one appears in Rosellon. Three surfaces $\varnothing=6-7$ aligned from Ebro's valley, following the Fosa Balear, arrive at Mallorca's SE, in a direction which is clearly perpendicular to the range of emergencies from Cabo de la Nao and the Ibiza, Mallorca and Menorca islands.

The zone is completed with the seismic lagoon of the proximities of the Ibiza, and other lagoons in the Mediterranean sea, in parts of Vasco-Navarra and the Ebro valley and in the whole French Midi strip.

C. - Occidental Zone; formed by the regions 11, 12,13,14, except for the two quadricles at the $\mathrm{SE}$, and the meridional remainder of region 7 . The zone extends in a different form to the $\mathrm{N}$ and more to the $\mathrm{E}$ than in the $R P$ sketch, and it widens in the South on the supposed Guadalquivir Fault continuation.

There is a general surface $\varnothing=6-7$, in which and to the NE of Iisbon, an intrusion lower than 6 is shown. On this general surface there is another of $\varnothing=7-8$, with accentuated enterings and salients. Then, from the Tajo estuary to the mouth of the Mira, the seismic activity reaches another more reduced one and is characterized by an intermediate focus earthquake. The other intermediate shocks are aligned on the Southern edge of this zone, as a probable occidental continuation of the Guadalquivir Fault.

D. - Meridional Zone; integrated by the regions $15,16,18,19,20$ and the Southern aggregation of region 9, one quadricle is in the SE corner of 8 , another in the corner of region 21 and two quadricles in region 14. Except for the widening towards the $N$, the zone follows the given by RP for the Peninsula, and is prolonged up to the edge of the area, including also Moroco's territory.

The zone has a surface $\varnothing=7-8$, in the SW of the area (Atlantic) and another seven of the same value; of those, the most meridional and extended one is located in Northern Moroceo and is intensified on 
the boundary of the area. Of the other six surfaces only one is exempt and is located in the Seno Gaditano; the rest, as the aforesaid one of Morocco, appear inserted into the half-close of curve $\varnothing=6$. This zone includes the Iberian mountain system and Maestrazgo massiveness, to the North.

There are three surfaces with different features, at the Southern Guadalquivir Fault. Taking them from $W$ to E, we can advise: 1st, a nucleus in Grazalema, resting on Alboran Fault, with an intermediate shock close to the Gibraltar strait; 2nd, the large surface concurring with the Mole Betica, $\varnothing=8-9$, which includes the sole deep focus, reaches values higher than 9 in this border and two others to the North of the Guadalquivir (Bailen), and 3rd, a maritime zone at the SE Cabo de Gata, resting on what we have called the Alboran Fault by an intermediate focus earthquake. If this last epicenter is linked with the one on the Algerian coast, the line cuts the low seismicity strike iniciated in Ibiza which serves as a border between the $\mathrm{D}$ and $\mathrm{E}$ zones, which does not seem very likely, though we have not sufficient data to draw any conclusions. The last of those surfaces $\varnothing=7-8$ appears in the Peninsular Levante, boundered as the $S$ by the Sangonera river and the lower basin of Segura.

Zone $\mathrm{D}$ is the most important one in the area, from the seismic point of view, and it plants many points of interest which should be objects of future studies, on the basis of a wider colaboration in different fields: Geotectonics, Geology, Hidrographics and Geophysics.

E. - Algerian Zone; with the regions 21 and 22, exception is made of the quadricle belonging to 21 and attached to Zone $\mathrm{D}$. This zone $\mathrm{E}$ is clear and obviously extends more towards the East, outside the investigated area. The zone shows a clear separation with Zone I) and much more with Zone B; perhaps that is due to the scanty information since there are no seismological stations neither in Baleares nor in Northern Morocco.

Inside the strike $\varnothing=7-8$, three surfaces $\varnothing=8-9$ are prominent, of which only the most occidental one (Orleansville) reaches values $\varnothing>9$. The seismicity decreases towards the borders of the Southern area, with curving limits enterings and salients.

\section{Form of cumulative elastic strain releases.}

From the data quoted in Table IV, the values $\left(\sum E\right)^{1 / 2}$ have been obtained. These values are proportional to the elastic strain releases 
(see paragraph III.3) and are plotted on a graph (Fig. 9) with ordinates expressed in $10^{11}(\mathrm{erg})^{1 / 2}$. We can observe that this elastic strain has been accumulating during the interval 1906.1909 until 1951.1954, in the 50 years with the lowest seismic activity. The accumulated energy has been released abrutly in 1951 and 1954. The earthquakes which

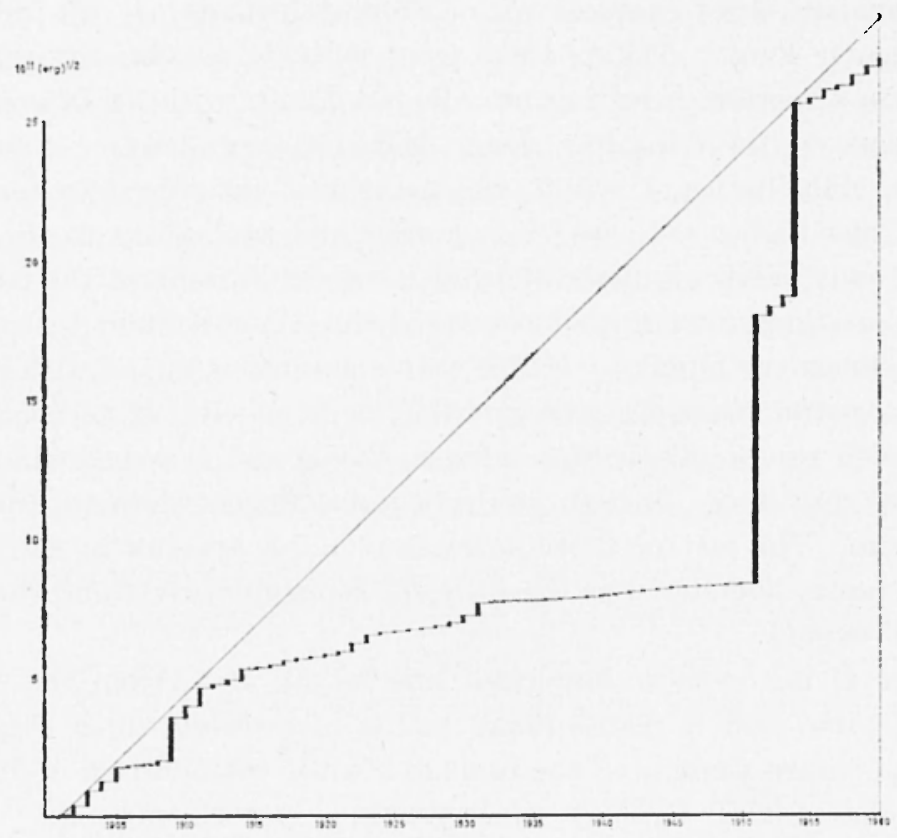

Fig. 9 - Cumulative strain release variation.

occurred at Bailen (1951) and in Alpujarras and Algeria (1954) have produced the high seismicity of these two years. There are four important shocks, designated by the ordinal numbers 2881, 2898, 3052 and 3068 in the list published in Ref. $b$ ). The energy released by these four shocks belongs almost completely to the whole instrumental period; the strain considered is $\left(\sum E_{60}\right)^{1 / 2}$ and not $\sum_{60}\left(\sum E\right)^{1 / 2}$.

For 1951, the shocks No 2881 ( $h=100 \mathrm{~km}$, Andujar) and No 2898 ( $h=140 \mathrm{~km}$, Jaen) were both studied by Bonelli and Esteban Carrasco (1953), who located the focei at an infrequent depth and in a teritory where isostatic descompensation exists as noted by the studies of Sins and Lozano (1948). This seems to indicate a possible fracture under the Sierra Morena range, to the $\mathrm{N}$ of the Guadalquivir Fault and with an approximate direction to the NE. The magnitude was not deduced from the records, for which reason admits the possibility that the $S D$ 
estimates were perhaps higher than the magnitude corresponding to each earthquake.

In 1954 two shocks occurred, No 3052 (Durcal), the only one with great hypocentral depth ( $h=0.09 R$, from I.S.S.), studied by several seismologists and which is mentioned in pertinent literature for its character comparable to the deep New Zealand earthquakes, and No 3068 (Orleansville), a shallow very destructive shock more widely and more carefully studied on the basis of macroseismic and microseismic data. The magnitude corresponding to the second shock, given in $S D$, is in agreement with the value accepted by Rothe (6 3/4); regarding the magnitude of the first shock, there may exist a possible difference of $1 / 4 \mathrm{~m}$, in excess.

We belive it unnecessary to correct the magnitude of both shocks, because of the actual uncertainity in the empirical formula applicable to its computation. The values listed in $S D$ were obtained by a systematic criterion for all shocks of this information and it was expressly advised that a certain value for a determined shock, as much in magnitude as in the epicentral coordinates or depth, is affected by different errors of the estimated averages for all the earthquakes included in each epoch; these epochs were established with the purpose of homogenizing the material as much as possible. On the other hand, the correction for the $m$ values in the four aforesaid shocks might not change essencially the shape of strain accumulation and release, though it is evident a consequent slope variation of the surrounding straight because the quantitative aspect.

Between the two years of noticeable elastic strain releases which are united with the surrounding straight $\left(\sum E\right)^{1 / 2}$, the interval is of the same order as the return period which was estimated as likely for taking the place of a destructive earthquake, in the area; this determination was made in Ref. d) following another method. Both results are, more or less, a half of a Century.

\section{IV. - COMPARATIVE SKETCH OF SEISMICITY WITH OTHER DATA.}

\section{The Alpine Geosyncline.}

Suess and other authors gave the first opinions about the continuity of the main orogenic lines of Europe. These directions of the foldens, with regard to the Peninsula Iberica, are shown in the four graphs of Fig. 10 and they coincide with the line of the Penibetica with some variations in the occidental end of the Straits of Gibraltar. The 

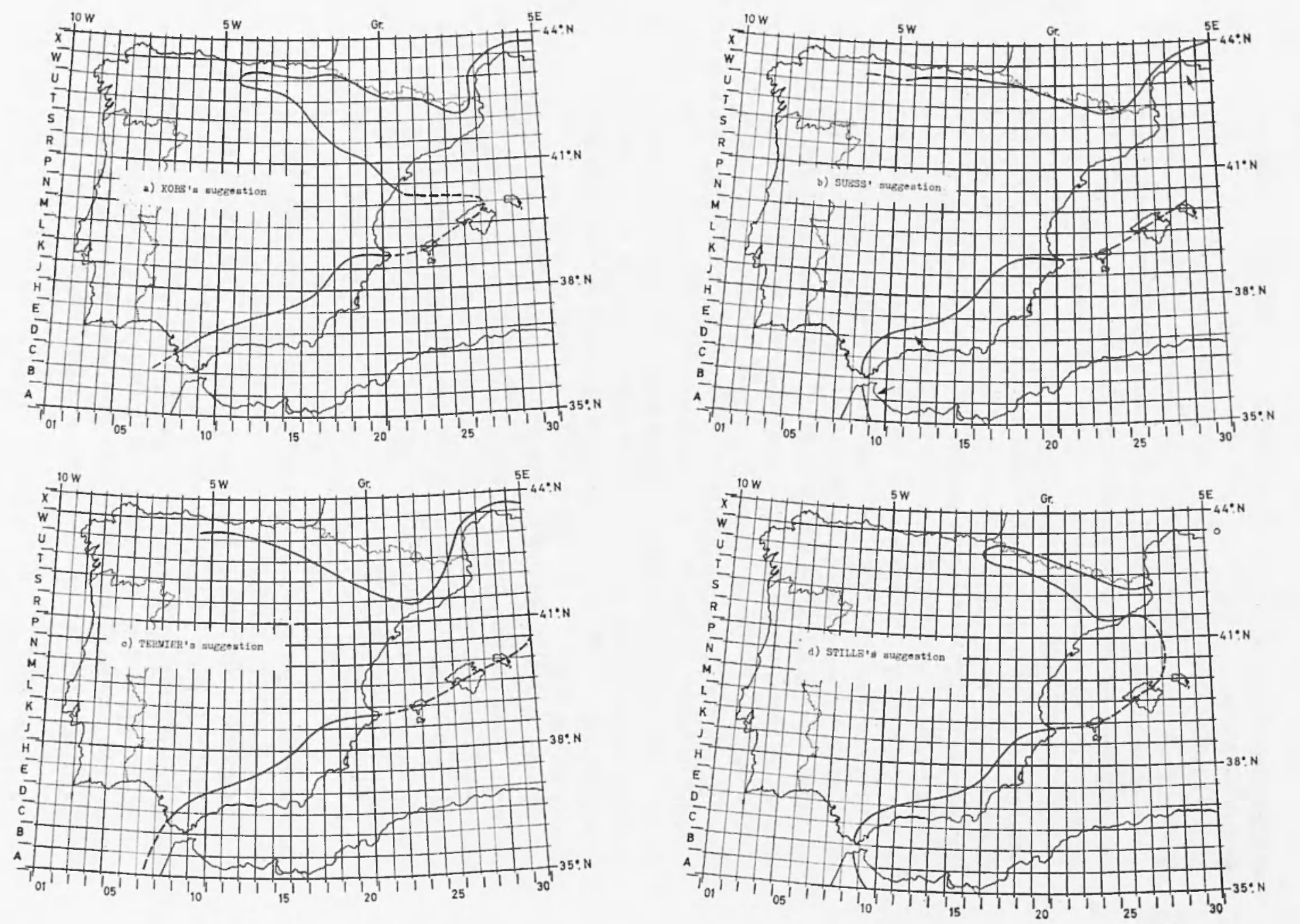

Fig. 10 - Different orogenesis lines. 
alignments follow the Balearic Islands almost, always over the two islands of Ibiza and Mallorea. The Pyrenees appear directly linked (Stille) wheither through the Iberian Cordillera (Kobe) or independently. The stress directions are already indicated in the Suess' studies.

The folden are subordinate to the geosyncline, for which reason this drawing may be compared with seismicity. Fig. 11 shows a sketch of the Western Mediterranean Oval of the Mediterranean Alpine Geosyncline, marked by a full and heavy line, following Beloussov's (1962) description. The Pyrenees Oval is self-contained and not connected to the main body of the geosyncline, while the Celtiberian Oval, which was studied by Brinkmann, in 1931, and by Richeter and Teichmueller, in 1933, is connected to the geosyncline and to South of the Ebro's Valley. The occidental end of the Mediterranean Geosyncline passes through the West of the Gibraltar Strait and does not continue beneath the Atlantic waters.

It may be observed that the highest seismicity zones in the studied area are inside the oval of the Geosyncline, save for several exceptions, as in Zone $\mathrm{C}$, where seismic regions located on the Platform appear, and its causes should be looked for in the local tectonic and other geophysic features. There are other less interesting surfaces in Zone A and also on the Platform, such as the nucleii at NW of the area and several points proceeding from shocks with shallow or very shallow focei.

On the location of intermediate depth shocks in the Seno Gaditano, there is an alignment which perhaps agrees with a possible Guadalquivir Fault continuation and which suggests the way $G F$ goes back to the Straits of Gibraltar. If this question is verified it has to be considered a Gaditan Oval at the W end of the Geosyneline beneath the no-oceanic of the Atlantic waters because in this region the bathimetric cotes are lower than $2,000 \mathrm{~m}$. Linking the intermediate shocks of the Alboran Sea, from Grazalema at the NE and from Cabo de Gata at the NW, the half-close formed surrouns the Sub-Betica Serranias and the whole of Mole Betica, and on this account a rough draft suggests another possible oval almost closed and connected to the Geosyncline, perhaps in the same $G F$. These suggestions are not at all firm conclusions but only conjectures, which need nuch conscientious research in these regions, on basis of copious and careful instrumental observations.

A continuous line passing between the eurves $6<\varnothing<7$ in the different seismic nucleii on the obtained activity map and following as approximately as possible the Geosyncline direction, according to the description at the beginning of the present paragraph, would give 


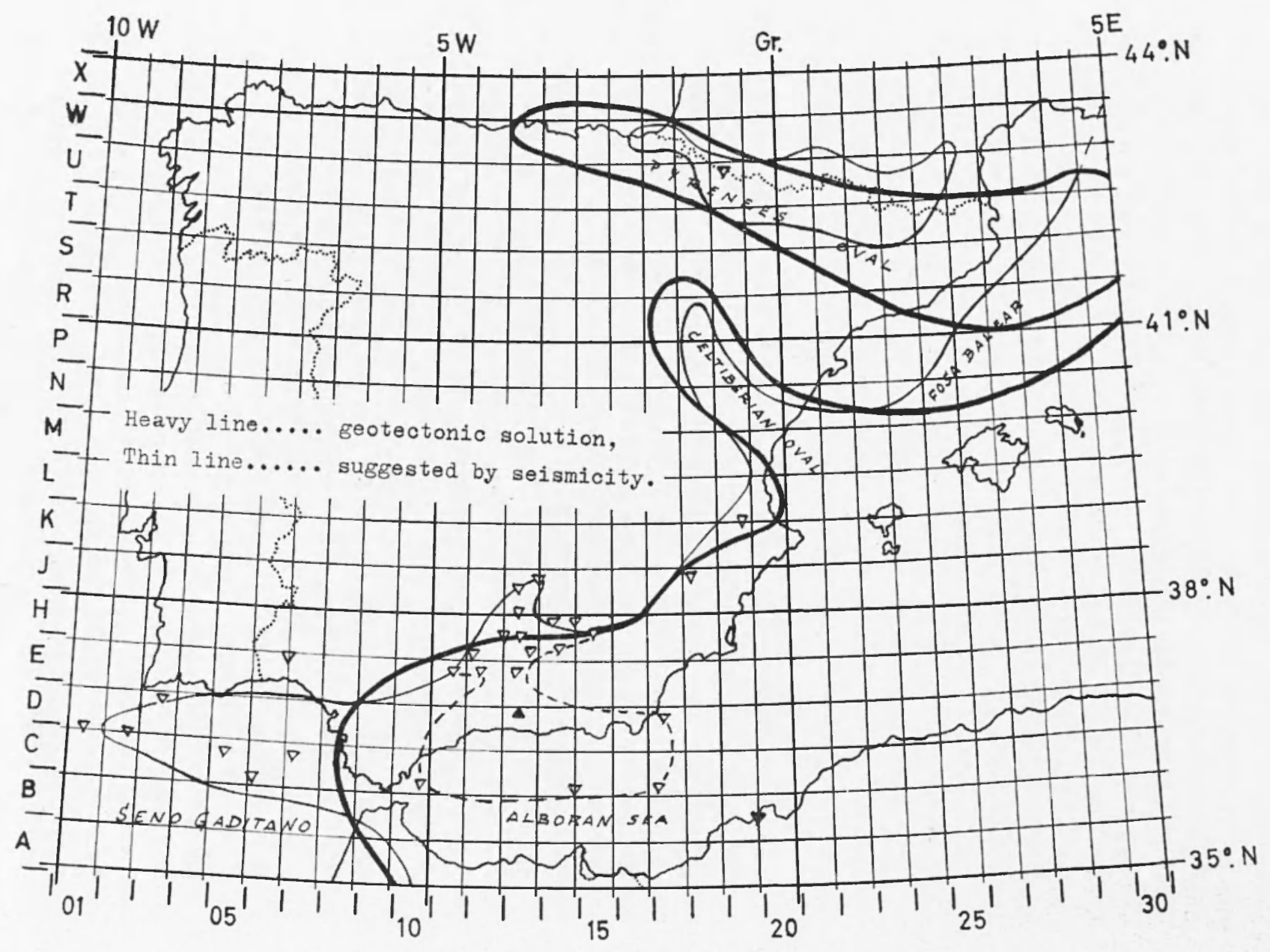

Fig. 11 - Alpine Geosyncline in the Western Mediterranean. 
a graphic solution fitting the intermediate shocks, and linking the Celtiberian Oval with its continuation in the Gulf of Lyon across the seismically active spot of the Fosa Balear, bordering the South of the seismic region of Catalonia, whose location, between the true geosyncline and the Pyrenees Oval, perhaps could be explained by the local tectonics. This continuous thin line drawn in Fig. 11 makes a possible direct comparison of the results deduced for the seismicity of the whole area.

\section{Comparison with regional Tectonics.}

Fig. 12 is a tectonic rough draft of the area drawn with data from the "Geotectonic Map of Europe" (1962) and the "Mapa Sismotectonico de la Peninsula Iberica" (1960). The figure has been drawn to show the main features of the Platform and Geosyncline; in particular, the general uplifts and subsidences. For the Geosyncline, the stabilized, or slower movements, are detached from the other intensive ones or those actually in course. For the Platform, the old uplifts withdraw the hercynian ones and the hercynian subsidences are disjoined from those which have occurred during Quaternary. Several basic rock intrusions, diapirism and extrusions are presented schematically. The directions of the large deep and active faults and thrusts have been drawn within a wide margin of approximation suficient for our purposes.

Generally speaking, it is possible to appraise that geotectonics and seismicity agree. Looking at the tectonic distribution of zone $\mathrm{C}$, we belive it accords with the features shown in the seismic map. In Zone A, the seismic surfaces at NW (Galicia and Asturias) accord with an extensive intrusion of basic rocks and with a fault, respectively. There is also concordance in Zone B, within the Pyrenees Oval, however the Geosyncline continuity from the Celtiberian Oval up to the $\mathrm{NE}$ of the area is not perfectly shown, because the Fosa Balear appears as a lower seismicity.

Zone $\mathrm{E}$ seems equally in accordance with the tectonic elements; enlarged valleys between uplifting cordilleras and other zones with intensive differential movements between contiguous blocks. It is impossible to analyze the maritime part as the tectonic is unknown. It is remarkable to note the appreciable seismicity in the inter-oceanic; region, inside the true oval at the occidental end of Geosyncline. And also, the low seismicity beginning at the bathimetric cote $2,000 \mathrm{~m}$ and up to the E-NE, in the Mediterranean sea. 


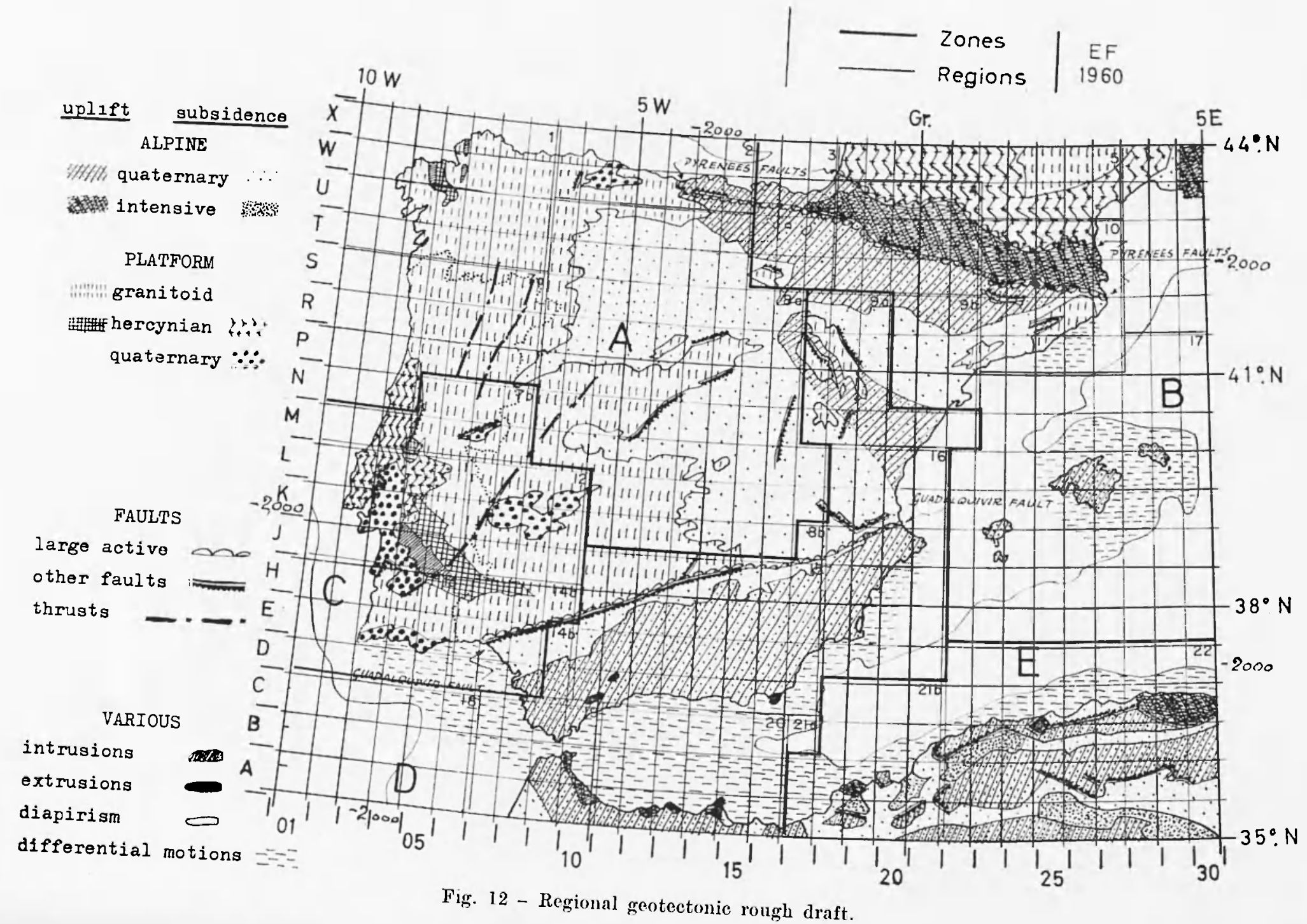

Fig. 12 - Regional geotectonic rough draft. 
To the North of Bailen the tectonic map shows the joint direction of two faults appearing near the deep fault; this direction agrees with the location corresponding to the two intermediate shocks No 2881 and No 2898, which occurred in 1951. The geotectonic map underlines the maritime zones included between the coasts of Portugal-Spain and Morocco-Algeria, where differential movements between the contiguous blocks are evident. This indication, stopping in the proximities of Ibiza, extends over the whole of the Alboran Sea and Seno Gaditano, regions of sharp seismic frequency, though the energy released is not of such an amount as in other regions of the area.

To facilitate the comparison between tectonies and seismicity, the boundries of seismic zones A, B, C, D, F, have been superposed on the tectonic map.

\section{Comparison with gravimetric results.}

We would have preferred to have a gravimetric map of the whole area expressing Airy's hypothesis. For a part of the Peninsula, Lozano (1948) computed the isostatic anomalies by means of the Heiskanen system, on the assumption of a thick crustal structure of $40 \mathrm{~km}$ and utilizing the Cassinis normal gravity formula of 1930. Fig. 13 reproduces, with an equidistance of $30 \mathrm{mgl}$, a part of the sketch deduced by the Lozano study. We can observe the arch of the negative anomalies which the Penibetica System draws and which is in coincidence with a seismic activity zone. The points of anomalies -38 and $-75 \mathrm{mgl}$ are also in very approximate coincidence with other overtoping seismic activity points of different values of $\varnothing$.

The Servicio de Gravimetria of IGC (Gravimetric Survey, Instituto Geografico y Catastral) published in 1948 five gravimetric maps with Bouguer's anomalies representing the differences between the observed and the theoretical gravity deduced from the corresponding two-axis ellipsoids by Helmert, 1901-1905, Bowie, 1917, Cassinis, 1930, and Heiskanen, 1938, formulas. Fundamentally, these maps refer to the Spanish peninsular territory, with only a slight reference to the territory of Portugal. In 1958, Portugal prepared a Bouguer's anomaly map of its territories. This map was publicated in scale $1: 1.000,000$ and equidistance of $5 \mathrm{mgl}$, while the Spanish maps were drawn in seale 1:3.000.000 and equidistance of $10 \mathrm{mgl}$. The writer has remelted the Portuguese map and the last of the five Spanish maps as well as drawn the sketch of Fig. 14, with curves equidistanted $30 \mathrm{mgl}$. We lave also superposed 


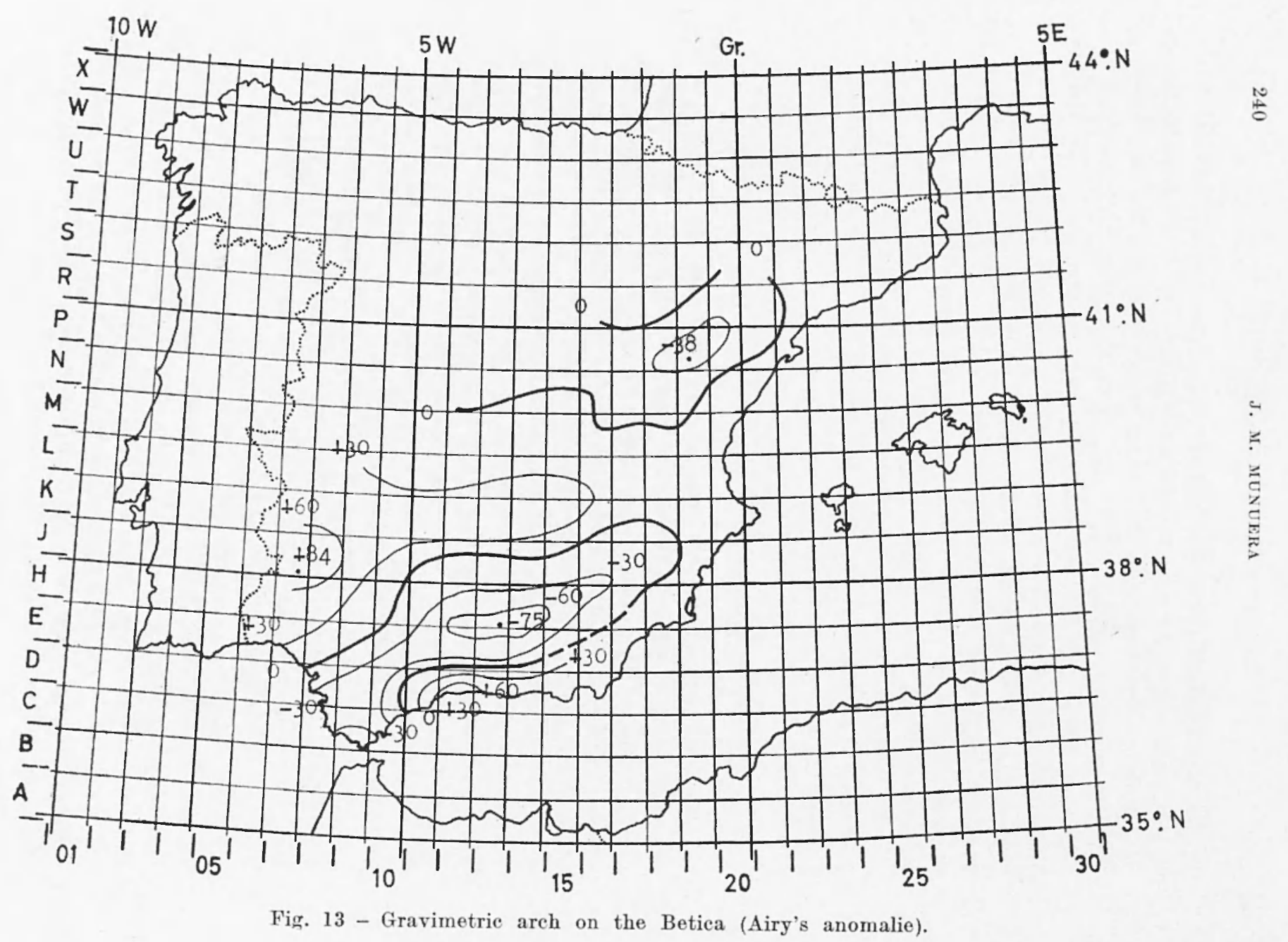




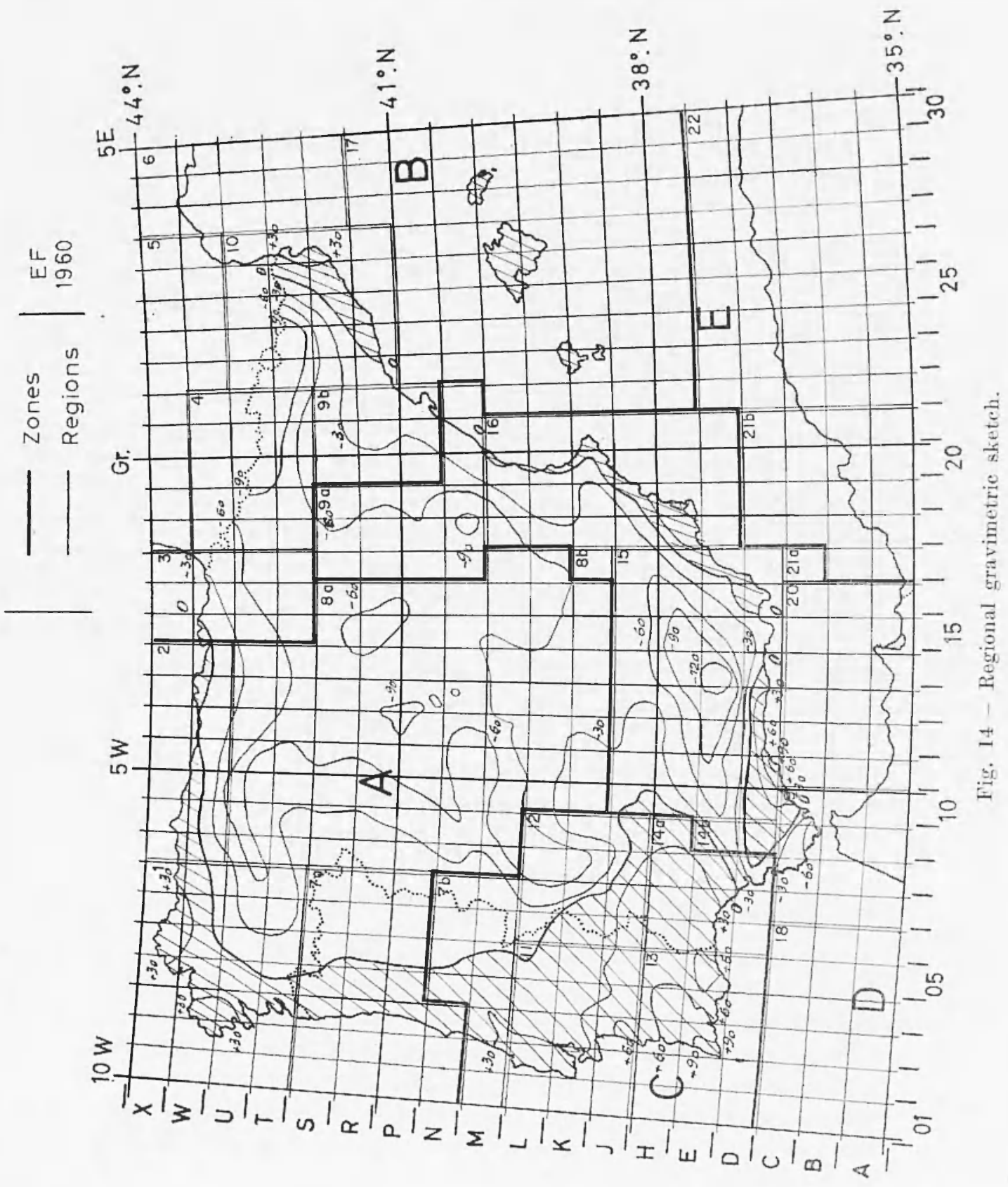


on the mentioned figure the bounds of the seismic zones, as it is done in the tectonic and geomagnetic maps.

From this figure an immediate agreement between gravimetric and seismic data is dedueed, within the Pyrenees Oral and the Celtiberian Oval. The zones A, B, C, give a very good conformity between gravimetrics and seismicity; i.e., the seismic nucleii towards $N$ and SW of Zone A (Galicia) have the same external appearence as that indicated by the isanomals of $+30 \mathrm{mgl}$. As for the line of separation of the positive and negative anomalies, which frankly extends to the SE and ends in the Guadalquivir, it presents a noticeable agreement with the seismic hipsometries of Zone $\mathrm{C}$. You can note inflexions of the gravimetric isanomals best fitting with the $\varnothing$ hipsometries.

For the Andatusian region, it can be observed:

1) to the SW, the gravity isanomals seem to agree with a form of the Alpine Geosyncline regression, perhaps somewhat more towards E than indicated by the linked intermediate shocks,

2) in the Alpujarras (Sierra Nevada) nucleus there is a clear agreement between Gravimetry, Seismicity and Geotectonics, not only in the valnes of the anomaly but also in the sharp gradient near Motril and the dissappearance of the positive anomaly on the coast,

3) upward towards E, the tendency of the gravimetric map, though in agreement with the Geosyncline, does not correspond with the seismic activity map neither in the location of surfaces $\varnothing=7-8$, nor in the alignments of the intermediate depth shocks,

4) an explanation should be found not only for the line of the Seno Gaditano bottoms but also for that of the Alboran Sea. Unfortunately, there are no gravimetric data for these regions.

\section{Comparison with geomagnetic results.}

In order to compare with seismicity, it whould be convenient to have a map which represents the differences between the modular normalized values of the geomagnetic field vector, $F$, and the observed values. The Peninsula Tberica geomagnetic map, reduced to the date 1 st January 1960 was effectuated by the colaboration of the Serviço Meteorologico Nacional de Portugal (Portuguese National Meteorological Service) with the Instituto Geografico y Catastmal de España (Spanish Geographic and Cadastral Institute). This map is presented in three figures, scale $1: 2.500,000$, for $H, Z, D$, elements. 
There appear twelve areas in coincident location in the three elements and also several points with different and smaller anomalies. In the Servicio de Geomagnetismo y Aeronomia (Aeronomy and Geomagnetism Survey), IGC, a part of the normalized values has been computed by an IBM 1620 machine, but the results of the obtained differences are not yet available and in graphic form, though a drawing of $F$-map is being carricd out at present.

In the general shape of the horizontal and vertical isodynamics (the isogonal map is not of interest for our purposes) no remarkable differences have been appraised, except for the said variable points corresponding to the anomalous stations (there are not many of them), the 12 common zones with noticeable anomalies and a slight alteration on the curve $0.336 \Gamma$, of $Z$, between NIotril and Almeria, bending on the coast to the South of the Sierra Nevada body (Alpujarras). By this conformity of the $H, Z$, forms we have utilized only the map corresponding to the horizontal isodynamies, as Fig. 15 shows, with equidistances of $200 \gamma$ and with the anomalies enumerated from North to South.

Anomaly No 1, aligned from the NE to the SW, coincides in location and direction with the data from the tectonic and seismic maps. It is a positive anomaly reaching close to $300 \gamma$, in its interior. The $0.222 \Gamma$ curve bends in the $\mathrm{N}$ end and has a tendency towards inversion, near the Cape Estaca de Bares. Anomaly No 2 is caused by ferriferous sedimentary deposits.

Zone $\mathrm{C}$ includes the 10 geomagnetic remaining anomalies extending from the Cape of Roca, at the W of Lisbon, to the Saro Vicente Cape. in the $\mathrm{S}$ extreme of Portugal, and from the surroundings and East of Badajoz up to the NE of Sevilla. These anomalies have the following approximated values, on the corresponding curves:

$\begin{array}{cc}\text { Anomaly } & \gamma \\ 3 & +250 \\ 4 & +250 \\ 5 & -650 \\ 6 & +280 \\ 7 & -100 \\ 8 & +600 \\ 9 & +700 \\ 10 & -500 \\ 11 & -400 \\ 12 & -300\end{array}$




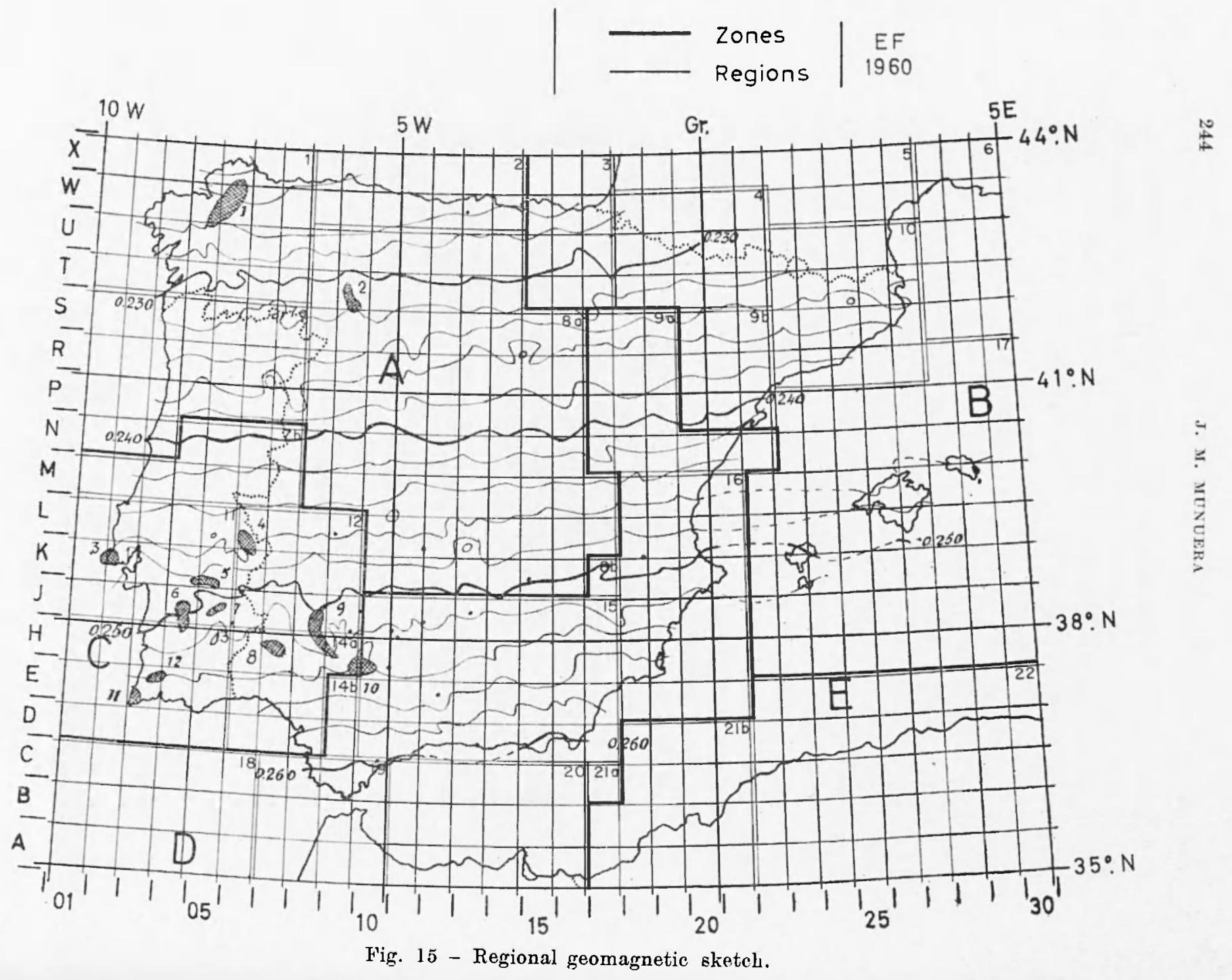


and they are located in notable concordance with the tectonic data. All geomagnetic anomalies belong to the region with positive gravimetric anomaly and outside the Alpine Geosyncline. The rest of the area does not show any interesting data for a seismic comparison.

It may be conjectured that most anomalous surfaces indicate the existence of strongly polarized masses in divergence with the actual geomagnetic field and that they lie with various "dip of a stratum" in the Platform. The coincidence with the contacting structures, as the tectonic map shows, suggest causes of the equilibrium disturbances between contiguous blocks, which could explain the recorded earthquakes in these places and the tendency towards a slow dicrease of activity, this seems to be confirmed by the revised data when the selected earthquakes list published in the Ref. b) was prepared.

\section{V. - Connents.}

The results obtained in the present study and in the preceding three on the same subject (*) could not establish any firm conclusions, although they show the main seismic features observed in the investigated area, especially in the Spanish peninsular territory.

The most noticeable features of energy, flux and conjunctive seismicity of the area could be found in the Summary of the present paper. Ref. b) includes the list of the selected earthquakes for study (3255 shoeks corresponding to 2360 years). Ref. c) adds the selected shocks up to 3307 and classifies them into conjectural and acceptable ones; practically, the shocks with acceptable location epicenters are those of the instrumental period, 1901-1960. With all the information reduced to 50 years, its weight was verified with an adjustment of the $\log N, m$, regression which gave a satisfactory parabolic shape. As a first approximation, the simple linear form $\log N=c-m$ was accepted; a map, scale $1: 2.000,000$, shows these epicenters symbolized by depth (shallow, intermediate, and one deep). No relation was found between either the hour, or the month with the frequency. Ref. $d$ ) is a probable frequency map for 50 years and for each $1000 \mathrm{sq} \mathrm{km}$, referring to degree VI of the international macroseismic scale and obtained as an extrapolation from the aforementioned approximate linear regression.

$\left(^{*}\right)$ Regarding Ref. $\left.\left.\left.\left.a\right), b\right), c\right), d\right)$ only the last three belong to the present seismic study program. 
Table V - ENERgY AND FLUX BY EVERY QUADRICle AND LAPSE.

\begin{tabular}{|c|c|c|c|c|c|c|}
\hline $\mathrm{Rg}$ & Qei & Shocks (SD ordinal) & Sum $E$ & $\varnothing$ & \multicolumn{2}{|c|}{ A verage } \\
\hline \multicolumn{7}{|l|}{$1901-1905$} \\
\hline 4 & $\begin{array}{l}\text { U20 } \\
\text { U21 }\end{array}$ & $\begin{array}{l}845-847 \\
786\end{array}$ & $\begin{array}{l}1.04(21) \\
1.10(17)\end{array}$ & $\begin{array}{l}9.4 \\
7.4\end{array}$ & 2.1 & $(20)$ \\
\hline 10 & $\mathrm{~T} 27$ & 806 & $1.10(17)$ & 7.4 & 2.5 & $(16)$ \\
\hline 11 & $\begin{array}{r}\text { K02 } \\
\text { J02 }\end{array}$ & $\begin{array}{l}822-850 \\
820\end{array}$ & $\begin{array}{l}1.04(21) \\
1.04(21)\end{array}$ & $\begin{array}{l}9.4 \\
9.4\end{array}$ & 4.2 & $(20)$ \\
\hline 16 & $\mathrm{~J} 19$ & 804 & $5.19(15)$ & 6.8 & 1.2 & (15) \\
\hline 22 & $\mathrm{C} 26$ & 823 & $4.90(19)$ & 8.7 & 9.8 & $(18)$ \\
\hline $1906-1910$ & & & & $\operatorname{area}=$ & 6.4 & (20) \\
\hline 1 & W04 & 1084 & $4.90(19)$ & 8.7 & 9.8 & (18) \\
\hline 6 & U 30 & 1000 & $1.04(21)$ & 9.4 & 2.1 & $(20)$ \\
\hline 10 & $\begin{array}{l}\mathrm{R} 24 \\
\mathrm{R} 25 \\
\mathrm{~S} 24\end{array}$ & $\begin{array}{l}898 \\
996 \\
986\end{array}$ & $\begin{array}{l}2.46(14) \\
2.32(18) \\
2.32(18)\end{array}$ & $\begin{array}{l}6.1 \\
8.1 \\
8.1\end{array}$ & 9.2 & (17) \\
\hline 11 & L02 & 908 & $2.46(14)$ & 6.1 & 4.9 & (13) \\
\hline 13 & $\begin{array}{l}\mathrm{D} 05 \\
1103\end{array}$ & $\begin{array}{l}904 \\
990\end{array}$ & $\begin{array}{l}1.10(17) \\
1.04(21)\end{array}$ & $\begin{array}{l}7.4 \\
9.4\end{array}$ & 2.1 & $(20)$ \\
\hline 15 & $\begin{array}{l}\text { D } 14 \\
\text { E } 13\end{array}$ & $\begin{array}{l}1041-1051 \\
1022\end{array}$ & $\begin{array}{l}9.80(19) \\
1.10(17)\end{array}$ & $\begin{array}{l}8.9 \\
7.4\end{array}$ & 2.0 & $(19)$ \\
\hline 16 & $\mathrm{~J} 19$ & $100 \bar{t}-1008$ & $4.91(19)$ & S. 7 & 9.8 & (18) \\
\hline 19 & $\mathrm{C} 10$ & 922 & $2.32(18)$ & 8.1 & 4.6 & (17) \\
\hline 21 & 1320 & 920 & $2.32(18)$ & 8.1 & 4.6 & (17) \\
\hline \multirow[t]{2}{*}{22} & B 27 & 1055 & $1.04(21)$ & 9.4 & 2.1 & $(20)$ \\
\hline & & & & area $=$ & 6.7 & $(20)$ \\
\hline
\end{tabular}

$\mathrm{Rg.}=$ region; Qcl. $=$ quadricle; $\varnothing=\log$. Flux; $(15)=10^{15} ; \mathrm{SD}="$ Seismic Data" 
(Tab. V, cont.)

\begin{tabular}{|c|c|c|c|c|c|}
\hline $\mathrm{Rg}$ & Qc & Shocks (SD ordinal) & Sum $E$ & $\varnothing$ & Average \\
\hline \multicolumn{6}{|l|}{$1911-1915$} \\
\hline 4 & $\begin{array}{l}\text { T'19 } \\
\text { U19 } \\
\text { U2 } 20 \\
\text { U2 } 21\end{array}$ & $\begin{array}{l}1259 \\
1111 \\
1162 \\
1241-1235\end{array}$ & $\begin{array}{l}5.19(15) \\
1.04(21) \\
5.19(15) \\
4.90(19)\end{array}$ & $\begin{array}{l}6.8 \\
9.4 \\
6.8 \\
8.7\end{array}$ & $2.2 \quad(20$ \\
\hline 7 & $\begin{array}{l}\text { M03 } \\
\text { M04 } \\
\text { N04 } \\
\text { P04 } \\
\text { R03 } \\
\text { R05 } \\
\text { S03 }\end{array}$ & $\begin{array}{l}1249-1251 \\
1149 \\
1185 \\
1285 \\
1164-1169-1203-1204-1278 \\
1205-1254-1291 \\
1093-1290\end{array}$ & $\begin{array}{l}1.10(17) \\
5.19(15) \\
5.19(15) \\
1.10(17) \\
4.97(17) \\
1.10(17) \\
4.64(18)\end{array}$ & $\begin{array}{l}7.4 \\
6.8 \\
6.8 \\
7.4 \\
8.3 \\
7.4 \\
8.2\end{array}$ & $1.1)(18$ \\
\hline 9 & $\mathrm{~N} 21$ & 1213 & $2.32(18)$ & 8.1 & $4.6(17)$ \\
\hline 10 & $\begin{array}{l}\mathrm{T} 24 \\
\mathrm{~T} 25 \\
\mathrm{~T} 26\end{array}$ & $\begin{array}{l}1244 \\
1100 \\
1151\end{array}$ & $\begin{array}{l}1.10(17) \\
1.10(17) \\
2.46(14)\end{array}$ & $\begin{array}{l}7.4 \\
7.4 \\
6.1\end{array}$ & $4 .+\quad(16)$ \\
\hline 11 & $\begin{array}{l}\text { J04 } \\
\text { J05 } \\
\text { K02 } \\
\text { K05 } \\
\text { L02 } \\
\text { L03 }\end{array}$ & $\begin{array}{l}1195 \\
1126-1132 \\
1119-1196-1197-1239-1243-1273 \\
1268 \\
1190-1248 \\
1233-1242\end{array}$ & $\begin{array}{l}2.32(18) \\
5.13(19) \\
5.39(19) \\
1.10(17) \\
2.43(18) \\
5.13(19)\end{array}$ & $\begin{array}{l}8.1 \\
8.8 \\
8.8 \\
7.4 \\
8.1 \\
8.8\end{array}$ & $3.2 \quad(19)$ \\
\hline 13 & $\begin{array}{l}\text { D04 } \\
\text { E03 } \\
\text { E04 } \\
\text { H04 } \\
1105\end{array}$ & $\begin{array}{l}1112 \\
1188 \\
1148-1250 \\
1092 \\
1127-1143\end{array}$ & $\begin{array}{l}2.32(18) \\
2.32(18) \\
2.43(18) \\
2.32(18) \\
2.32(18)\end{array}$ & $\begin{array}{l}8.1 \\
8.1 \\
8.1 \\
8.1 \\
8.1\end{array}$ & $2.4 \quad(18)$ \\
\hline 15 & $\begin{array}{l}1) 14 \\
\text { E13 }\end{array}$ & $\begin{array}{l}1199 \\
1105\end{array}$ & $\begin{array}{l}4.90(19) \\
2.46(14)\end{array}$ & $\begin{array}{l}8.7 \\
6.1\end{array}$ & $9.8 \quad(18)$ \\
\hline 16 & $\begin{array}{r}\text { H18 } \\
\text { J18 }\end{array}$ & $\begin{array}{l}1099 \\
1001-1102-1130\end{array}$ & $\begin{array}{l}1.04(21) \\
1.04(21)\end{array}$ & $\begin{array}{l}9.4 \\
9.4\end{array}$ & $4.2 \quad(20)$ \\
\hline 18 & BOI & 1270 & $2.32(18)$ & 8.1 & $4.8 \quad(17)$ \\
\hline 22 & $\begin{array}{l}\mathrm{A} 23 \\
\mathrm{D} 26\end{array}$ & $\begin{array}{l}1173 \\
1110\end{array}$ & $\begin{array}{l}2.32(18) \\
2.32(18)\end{array}$ & $\begin{array}{l}8.1 \\
8.1\end{array}$ & $9.6 \quad(17)$ \\
\hline & & & & area & $6.9 \quad(20)$ \\
\hline
\end{tabular}


('Tab. V, cont.)

\begin{tabular}{|c|c|c|c|c|c|}
\hline $\mathrm{Rg}$ & Qel & Shocks (SD ordinal) & $\operatorname{Sum} E^{\prime}$ & $\varnothing$ & Average \\
\hline \multicolumn{6}{|l|}{$1916-1920$} \\
\hline 4 & $\begin{array}{l}\mathrm{T} 21 \\
\mathrm{~T} 22 \\
\mathrm{U} 18 \\
\mathrm{U} 22\end{array}$ & $\begin{array}{l}1441 \\
1295-1219 \\
1383 \\
1439\end{array}$ & $\begin{array}{l}1.10(17) \\
4.90(14) \\
1.10(17) \\
4.90(19)\end{array}$ & $\begin{array}{l}7.4 \\
6.3 \\
7.4 \\
8.7\end{array}$ & $0.98 \quad(19)$ \\
\hline 5 & $\mathrm{X} 25$ & 1414 & $1.10(17)$ & 7.4 & $0.22(19)$ \\
\hline 6 & T28 & 1370 & $5.19(15)$ & 6.8 & $1.04(15)$ \\
\hline 7 & $\begin{array}{l}\text { M04 } \\
\text { R0 I } \\
\text { R04 } \\
\text { R06 } \\
\text { S06 }\end{array}$ & $\begin{array}{l}1325 \\
1486 \\
1390 \\
1387-1413-1416 \\
1312\end{array}$ & $\begin{array}{l}1.10(17) \\
4.90(19) \\
2.32(18) \\
2.54(18) \\
1.10(17)\end{array}$ & $\begin{array}{l}7.4 \\
8.7 \\
8.1 \\
8.1 \\
7.4\end{array}$ & $1.08 \quad(19)$ \\
\hline 9 & $\begin{array}{l}\text { P21 } \\
\text { R22 }\end{array}$ & $\begin{array}{l}1438 \\
1329\end{array}$ & $\begin{array}{l}2.46 \text { (14) } \\
2.46(14)\end{array}$ & $\begin{array}{l}6.1 \\
6.1\end{array}$ & $0.98 \quad(14)$ \\
\hline 10 & $\begin{array}{l}\mathrm{R} 25 \\
\mathrm{R} 27 \\
\mathrm{~S} 25 \\
\mathrm{~S} 26 \\
\mathrm{~T} 23 \\
\mathrm{~T} 25 \\
\mathrm{~T} 27\end{array}$ & $\begin{array}{l}1354 \\
1360 \\
1468 \\
1303-1306 \\
1361 \\
1341 \\
1349-1351\end{array}$ & $\begin{array}{l}2.32(18) \\
1.10(17) \\
1.10(17) \\
2.19(17) \\
2.46(14) \\
1.16(13) \\
1.10(17)\end{array}$ & $\begin{array}{l}\text { 8. } 1 \\
7.4 \\
7.4 \\
7.6 \\
6.1 \\
5.5 \\
7.4\end{array}$ & $5.94(17)$ \\
\hline 11 & $\begin{array}{l}\text { K03 } \\
\text { K04 } \\
\text { I.05 }\end{array}$ & $\begin{array}{l}1328 \\
1339 \\
1389\end{array}$ & $\begin{array}{l}5.19(15) \\
2.31(18) \\
2.31(18)\end{array}$ & $\begin{array}{l}6.8 \\
8.1 \\
8.1\end{array}$ & $0.92(18)$ \\
\hline 15 & D 13 & 1326 & $4.90(19)$ & 8.7 & $0.98 \quad(19)$ \\
\hline 16 & $\begin{array}{l}\text { E } 20 \\
\text { H } 18 \\
\text { H } 19 \\
\text { J } 19 \\
\text { K19 } \\
\text { MI } 18\end{array}$ & $\begin{array}{l}1385-1386 \\
1330-1331 \\
1382 \\
1320-1415 \\
1324-1345-1376 \\
1422\end{array}$ & $\begin{array}{l}5.45(15) \\
4.90(19) \\
2.46(14) \\
5.45(15) \\
1.15(17) \\
2.46(14)\end{array}$ & $\begin{array}{l}6.8 \\
8.7 \\
6.1 \\
6.8 \\
7.4 \\
6.1\end{array}$ & $9.82(18)$ \\
\hline 17 & M26 & 1427 & $5.19(15)$ & 6.8 & $1.02(15)$ \\
\hline 18 & $\begin{array}{l}\mathrm{A} 01 \\
\mathrm{~B} 04\end{array}$ & $\begin{array}{l}1378 \\
1375\end{array}$ & $\begin{array}{l}2.46(14) \\
2.46(14)\end{array}$ & $\begin{array}{l}6.1 \\
6.1\end{array}$ & $0.98(14)$ \\
\hline 19 & A08 & 1477 & $2.46(14)$ & 6.1 & 0.49 (14) \\
\hline 20 & B 13 & 1450 & $2.46(14)$ & 6.1 & $0.49(14)$ \\
\hline 21 & $\begin{array}{l}\text { C17 } \\
\text { D18 }\end{array}$ & $\begin{array}{l}1397 \\
1404-1406\end{array}$ & $\begin{array}{l}2.46(14) \\
4.90(14)\end{array}$ & $\begin{array}{l}6.1 \\
6.3\end{array}$ & $1.27 \quad(14)$ \\
\hline & & & & area & $3.2 \quad(19)$ \\
\hline
\end{tabular}


(Tab. V, cont.)

\begin{tabular}{|c|c|c|c|c|c|}
\hline $\mathrm{Rg}$ & Qel & Shocks (SD ordinal) & Sum $E$ & $\varnothing$ & Average \\
\hline $1921-1925$ & & & & & \\
\hline 1 & U07 & 1524 & $2.64(14)$ & 6.1 & $0.53(14)$ \\
\hline \multirow[t]{5}{*}{4} & T19 & 1595 & $2.40(18)$ & 8.1 & \\
\hline & TI18 & 1690 & 2.64 (14) & 6.1 & \\
\hline & U 19 & 1622 & $4.90(19)$ & 8.7 & \\
\hline & U21 & 1647 & 5.19 (15) & 6.8 & \\
\hline & U22 & $1597-1612-1624$ & $1.15(17)$ & 7.4 & $1.30(19)$ \\
\hline 6 & $\mathrm{X} 28$ & 1700 & $2.64(14)$ & 6.1 & $0.53(14)$ \\
\hline 7 & $\mathrm{M} 04$ & 1688 & $1.10(17)$ & 7.4 & $0.22(17)$ \\
\hline 8 & $M 15$ & 1546 & $2.64(14)$ & 6.1 & $0.53(14)$ \\
\hline \multirow[t]{7}{*}{10} & $\mathrm{R} 25$ & 1587 & $1.10(17)$ & 7.4 & \\
\hline & $\mathrm{R} 27$ & 1618 & $2.64(14)$ & 6.1 & \\
\hline & S26 & 1530 & $2.64(14)$ & 6.1 & \\
\hline & $\mathrm{T} 25$ & $1527-1600$ & $1.10(17)$ & 7.4 & \\
\hline & T26 & $1518-1522$ & $2.57(14)$ & 6.1 & \\
\hline & U23 & 1570 & $1.10(17)$ & 7.4 & \\
\hline & U24 & 1562 & $4.90(19)$ & 8.7 & \\
\hline : & $\mathrm{L} 25$ & 1577 & $1.10(17)$ & 7.4 & $0.99(19)$ \\
\hline \multirow[t]{2}{*}{11} & K02 & 1531 & $1.10(17)$ & 7.4 & \\
\hline & L02 & 1671 & $1.10(17)$ & 7.4 & $0.55(17)$ \\
\hline \multirow[t]{6}{*}{13} & D01 & 1645 & $2.64(14)$ & 6.1 & • \\
\hline & 1) 05 & 1604 & 2.64 (14) & 6.1 & \\
\hline & EOI & 1566 & $2.64(14)$ & 6.1 & \\
\hline & E02 & $1523-1625$ & $1.10(17)$ & 7.4 & \\
\hline & E04 & 1648 & $1.10(17)$ & 7.4 & \\
\hline & $\mathrm{H} 04$ & 1573 & $5.19(15)$ & 6.8 & $0.45(17)$ \\
\hline 14 & $\mathrm{D} 07$ & 1672 & $1.10(17)$ & 7.4 & $0.22(17)$ \\
\hline \multirow[t]{5}{*}{15} & $\mathrm{D} 12$ & 1589 & $2.64(14)$ & 6.1 & \\
\hline & D13 & $1669-1670$ & $4.91(14)$ & 6.3 & \\
\hline & D 14 & $1585-1588$ & $4.91(14)$ & 6.3 & \\
\hline & D 16 & 1682 & 1.16 (13) & 5.4 & \\
\hline & E 13 & $1646-1659$ & 2.32 (18) & 8.1 & $0.48(18)$ \\
\hline \multirow[t]{4}{*}{16} & $\mathrm{E} 20$ & 1627 & 2.64 (14) & 6.1 & \\
\hline & J 19 & 1496 & 5.19 (15) & 6.8 & \\
\hline & $\mathrm{K} 20$ & $1560-1662$ & $2.32(18)$ & 8.1 & \\
\hline & $\mathrm{L} 20$ & 1696 & 2.64 (14) & 6.1 & 0.48 \\
\hline \multirow[t]{3}{*}{17} & $\mathrm{M} 25$ & 1693 & 2.64 (14) & 6.1 & \\
\hline & $M 26$ & 1694 & 2.64 (14) & 6.1 & \\
\hline & N24 & 1608 & 1.10 (17) & 7.4 & $0.22(17)$ \\
\hline
\end{tabular}


(Tab. V, cont.)

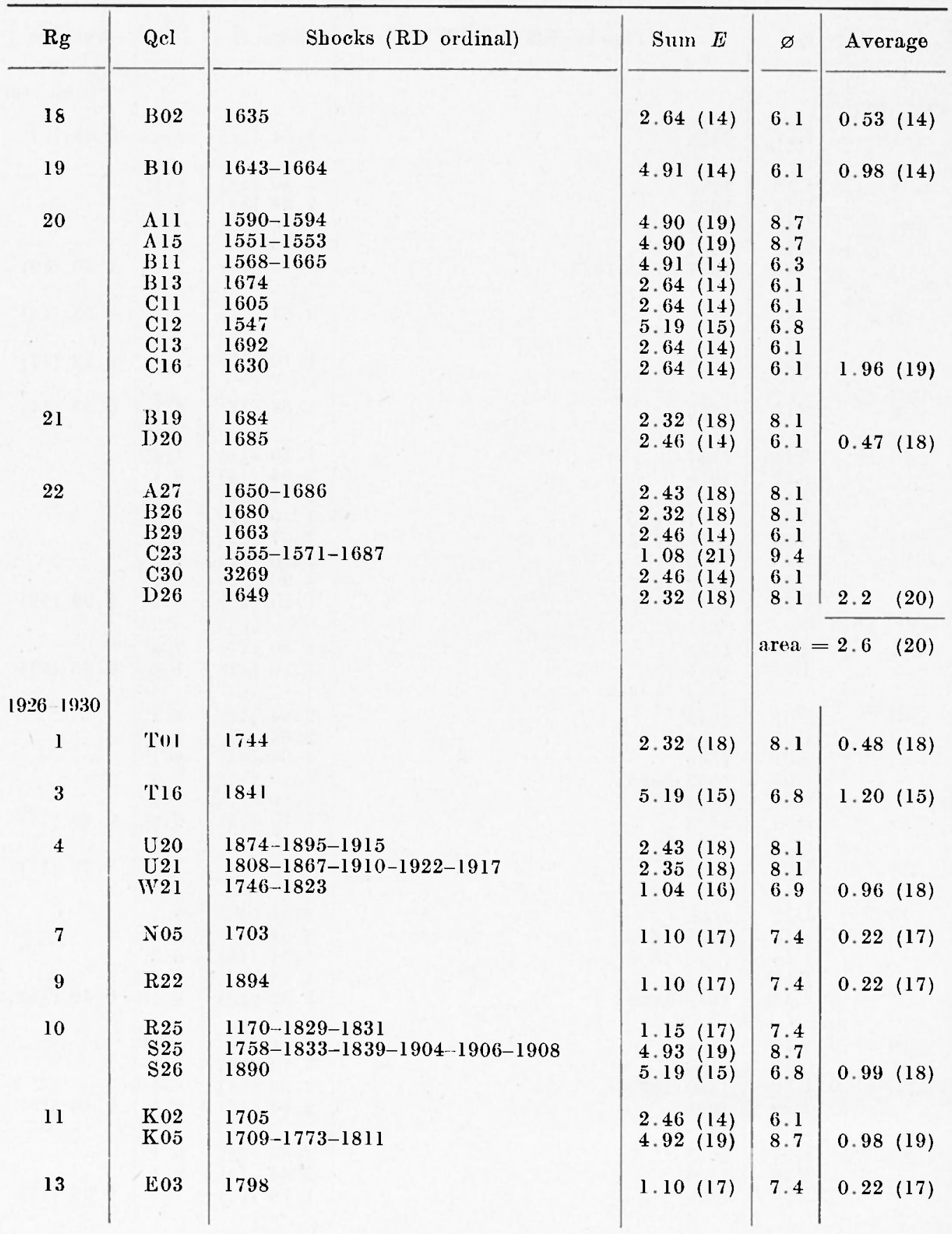


(Tab. V, cont.)

\begin{tabular}{|c|c|c|c|c|c|}
\hline $\mathrm{Rg}$ & $\mathrm{Qel}$ & Shocks (SD ordinal) & Sum $E$ & $\varnothing$ & Average \\
\hline 15 & $\begin{array}{l}\text { D } 10 \\
\text { D } 11 \\
\text { D14 } \\
\text { D15 } \\
\text { D16 } \\
\text { E12 } \\
\text { E13 } \\
\text { E16 } \\
\text { II } 11\end{array}$ & $\begin{array}{l}1726 \\
1760-1795-1797 \\
1742 \\
1712-1719-1771-1807 \\
1876 \\
1835-1865 \\
1814-1865 \\
1720-1899-1913 \\
1896\end{array}$ & $\begin{array}{l}2.32(18) \\
1.15(17) \\
1.10(17) \\
2.44(18) \\
1.10(17) \\
5.45(15) \\
1.04(16) \\
2.46(17) \\
4.90(19)\end{array}$ & $\begin{array}{l}8.1 \\
7.4 \\
7.4 \\
8.1 \\
7.4 \\
6.8 \\
6.9 \\
7.4 \\
8.7\end{array}$ & $1.08 \quad(19)$ \\
\hline 16 & $\begin{array}{l}\text { E } 18 \\
\text { J18 }\end{array}$ & $\begin{array}{l}1796 \\
1903\end{array}$ & $\begin{array}{l}2.46(14) \\
1.10(17)\end{array}$ & $\begin{array}{l}6.1 \\
7.4\end{array}$ & $0.22(17)$ \\
\hline 19 & $\begin{array}{l}\text { A10 } \\
\text { B09 } \\
\text { C10 }\end{array}$ & $\begin{array}{l}1900-1918 \\
1729 \\
1725-1727\end{array}$ & $\begin{array}{l}1.04(21) \\
2.46(14) \\
2.43(18)\end{array}$ & $\begin{array}{l}9.4 \\
6.1 \\
8.1\end{array}$ & $0.21(21)$ \\
\hline 20 & $\begin{array}{l}A 11 \\
A 12 \\
A 13 \\
A 14 \\
A 15 \\
A 16 \\
\text { B } 16 \\
\text { C13 } \\
\text { C14 } \\
\text { C15 }\end{array}$ & $\begin{array}{l}1735 \\
1730-1731-1734 \\
1784-1785-1787-1898 \\
1738 \\
1732-1737-1740-1790-1793 \\
1847 \\
1800 \\
1766-1858 \\
1736-1783-1784-1832 \\
1825\end{array}$ & $\begin{array}{l}2.46(14) \\
4.90(19) \\
4.90(19) \\
5.19(15) \\
4.90(19) \\
1.10(17) \\
2.46(14) \\
1.11(17) \\
1.16(17) \\
2.46(14)\end{array}$ & $\begin{array}{l}6.1 \\
8.7 \\
8.7 \\
6.8 \\
8.7 \\
7.4 \\
6.1 \\
7.4 \\
7.4 \\
6.1\end{array}$ & $0.29(20)$ \\
\hline 21 & A 19 & 1837 & $2.37(18)$ & 8.1 & $0.49(18)$ \\
\hline 22 & $\begin{array}{l}\mathrm{A} 28 \\
\mathrm{~B} 22 \\
\mathrm{C} 23\end{array}$ & $\begin{array}{l}3271 \\
1824 \\
1821\end{array}$ & $\begin{array}{l}5.19(15) \\
4.90(19) \\
1.10(17)\end{array}$ & $\begin{array}{l}6.8 \\
8.7 \\
7.4\end{array}$ & $0.98 \quad(19)$ \\
\hline $1931-1935$ & & & & area $=$ & $=2.7(20)$ \\
\hline 4 & $\begin{array}{l}\text { U } 20 \\
\text { I } 21\end{array}$ & $\begin{array}{l}2040 \\
2093\end{array}$ & $\begin{array}{l}5.19(15) \\
2.46(14)\end{array}$ & $\begin{array}{l}6.8 \\
6.1\end{array}$ & $1.08(15)$ \\
\hline 8 & $\mathrm{~K} 17$ & 2048 & $1.10(17)$ & 7.4 & $0.22(17)$ \\
\hline 9 & $\begin{array}{l}\text { P17 } \\
\text { P19 }\end{array}$ & $\begin{array}{l}1966 \\
2019\end{array}$ & $\begin{array}{l}2.46(14) \\
2.46(14)\end{array}$ & $\begin{array}{l}6.1 \\
6.1\end{array}$ & $0.98(14)$ \\
\hline 13 & 1105 & 2122 & $2.46(14)$ & 6.1 & $0.49(14)$ \\
\hline
\end{tabular}


(Tab. V, cont.)

\begin{tabular}{|c|c|c|c|c|c|}
\hline $\mathrm{Rg}$ & Qcl & Shocks (SD ordinal) & Sum $E$ & $\varnothing$ & Average \\
\hline 15 & $\begin{array}{l}\text { D } 10 \\
\text { D } 12 \\
\text { D } 13 \\
\text { D } 14 \\
\text { D } 15 \\
\text { D } 16 \\
\text { E } 11 \\
\text { E } 12 \\
\text { E } 13 \\
\text { E } 15\end{array}$ & $\begin{array}{l}2047-2055-2141 \\
2001-2004-2067-2105 \\
2038 \\
2030-2057-2162 \\
2056 \\
2005 \\
2147 \\
2106-2135 \\
2109-2156-2158-2164 \\
1975-2077\end{array}$ & $\begin{array}{l}1.15(17) \\
5.46(15) \\
2.46(14) \\
5.45(15) \\
5.19(15) \\
5.19(15) \\
2.46(14) \\
1.10(17) \\
1.16(17) \\
4.90(19)\end{array}$ & $\begin{array}{l}7.4 \\
6.9 \\
6.1 \\
6.9 \\
6.8 \\
6.8 \\
6.1 \\
7.4 \\
7.4 \\
8.7\end{array}$ & $0.99(19)$ \\
\hline 16 & $\begin{array}{r}\text { E } 19 \\
\text { J } 18\end{array}$ & $\begin{array}{l}2071 \\
1933-2000\end{array}$ & $\begin{array}{l}5.19(15) \\
4.90(19)\end{array}$ & $\begin{array}{l}6.8 \\
8.7\end{array}$ & $0.98(19)$ \\
\hline 19 & $(: 10$ & 2073 & $1.10(17)$ & 7.4 & $0.22(17)$ \\
\hline 20 & $\begin{array}{l}\text { A12 } \\
\text { B } 11 \\
\text { B } 13 \\
\text { C11 } \\
\text { C13 } \\
\text { C14 } \\
\text { C15 } \\
\text { C } 16\end{array}$ & $\begin{array}{l}1959-2112-2165-2168 \\
1972 \\
1954 \\
2152 \\
2139 \\
2058-2166-2177 \\
2132 \\
1955\end{array}$ & $\begin{array}{l}3.81(17) \\
5.19(15) \\
2.46(14) \\
2.46(14) \\
1.16(13) \\
7.37(14) \\
1.10(17) \\
2.46(14)\end{array}$ & $\begin{array}{l}7.7 \\
6.8 \\
6.1 \\
6.1 \\
5.4 \\
6.3 \\
7.4 \\
6.1\end{array}$ & $0.99(17)$ \\
\hline 22 & $\begin{array}{l}\text { B24 } \\
\text { B26 } \\
\text { D24 }\end{array}$ & $\begin{array}{l}3272 \\
1974 \\
2121\end{array}$ & $\begin{array}{l}2.32(18) \\
1.10(17) \\
2.46(14)\end{array}$ & $\begin{array}{l}8.1 \\
7.4 \\
6.1\end{array}$ & 0.49 (18) \\
\hline $1936-1940$ & & & & area $=$ & $2.03(19)$ \\
\hline 2 & W13 & 2292 & $2.46(14)$ & 6.1 & $0.59(14)$ \\
\hline 4 & U20 & 2238 & $2.46(14)$ & 6.1 & 0.59 (14) \\
\hline 7 & R03 & 2232 & $1.10(17)$ & 7.4 & 0.22 (17) \\
\hline 8 & $\mathrm{~K} 17$ & 2266 & $5.19(15)$ & 6.8 & $1.04(15)$ \\
\hline 10 & S27 & 2410 & $2.46(14)$ & 6.1 & 0.49 (14) \\
\hline 11 & J01 & 2178 & $5.19(15)$ & 6.8 & $1.04(15)$ \\
\hline 12 & K07 & 2307 & $2.46(14)$ & 6.1 & 0.59 (14) \\
\hline
\end{tabular}


(Tab. V, cont.)

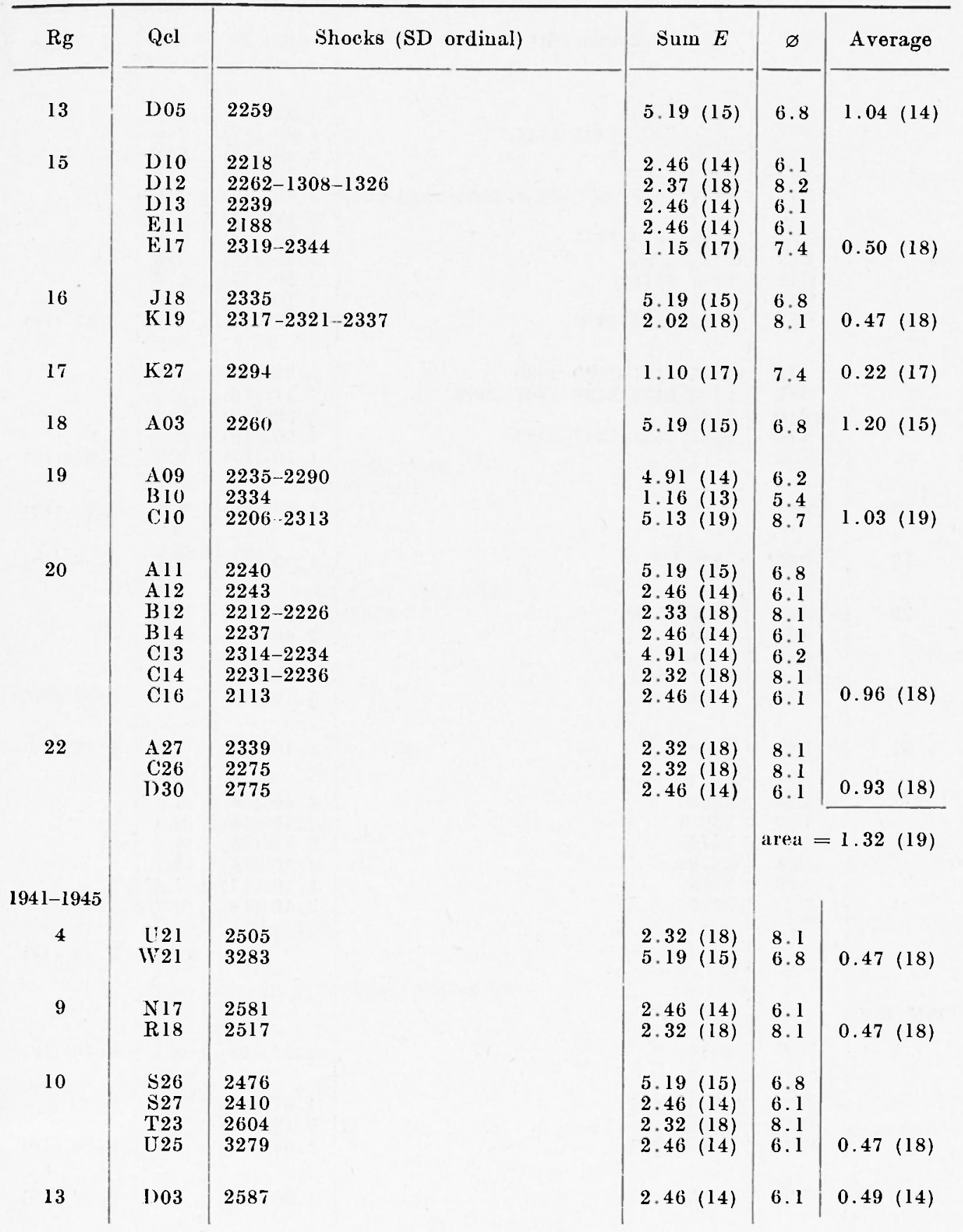


(Tab. V, cont.)

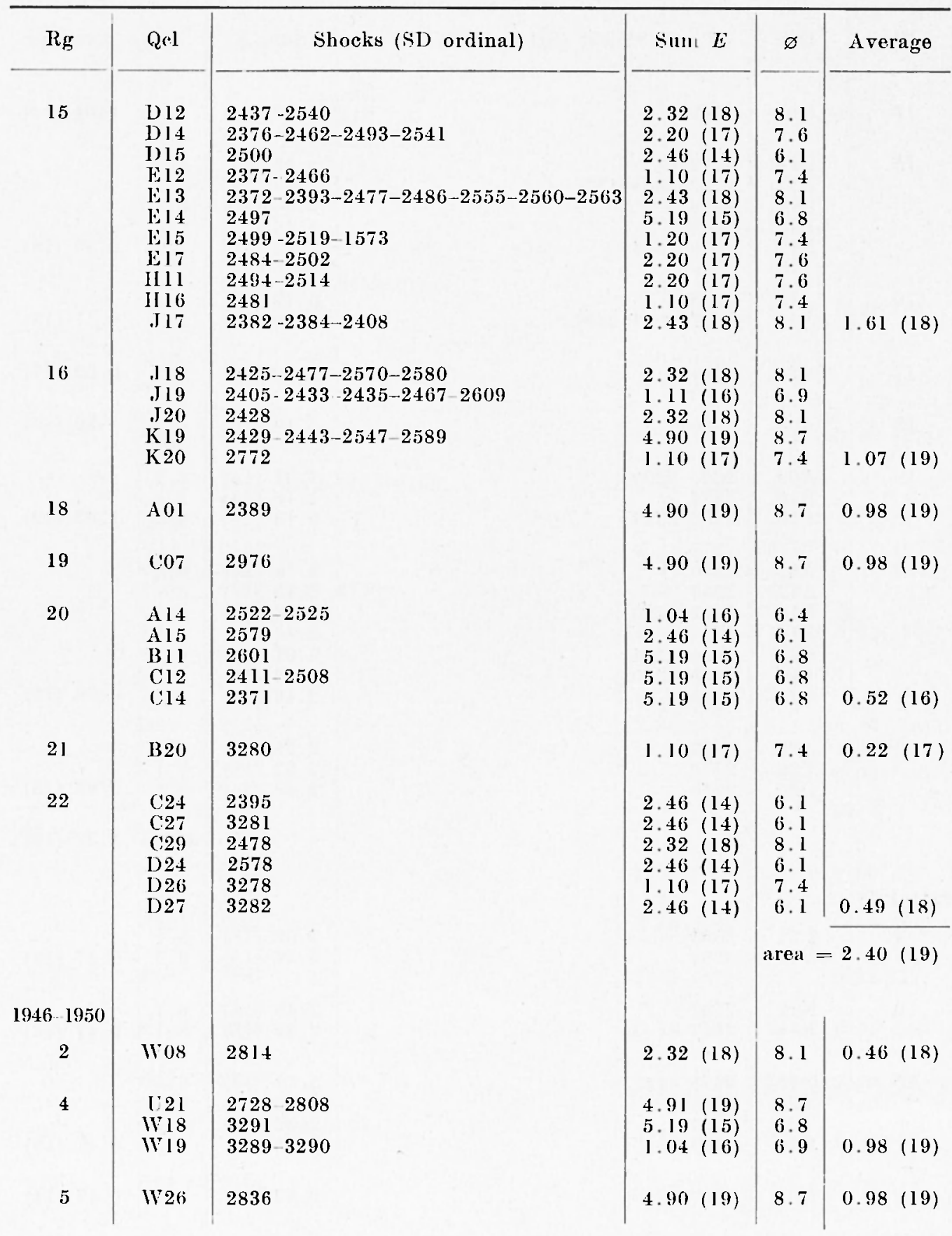


(Tab. V, cont.)

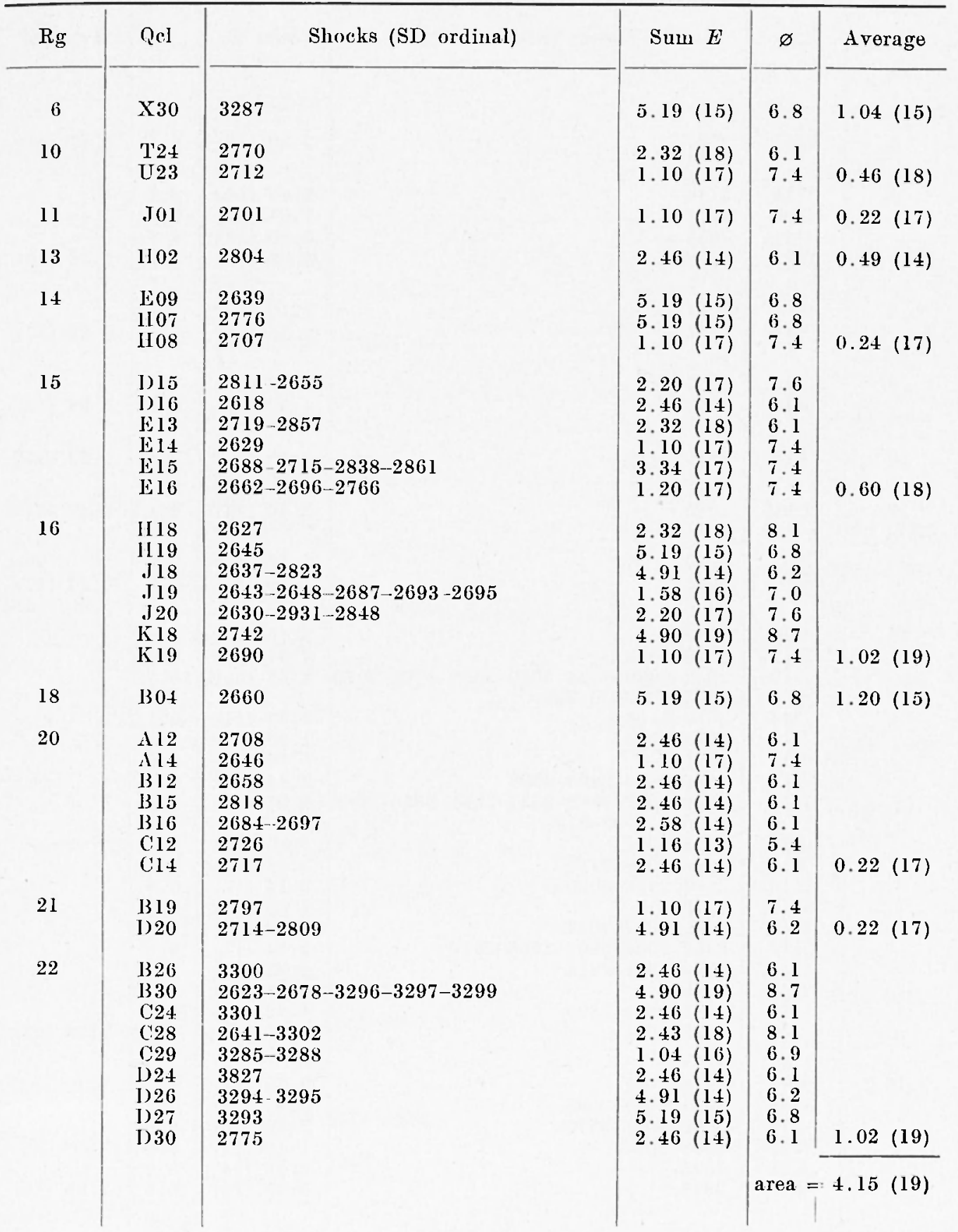


(Tab. V, cont.)

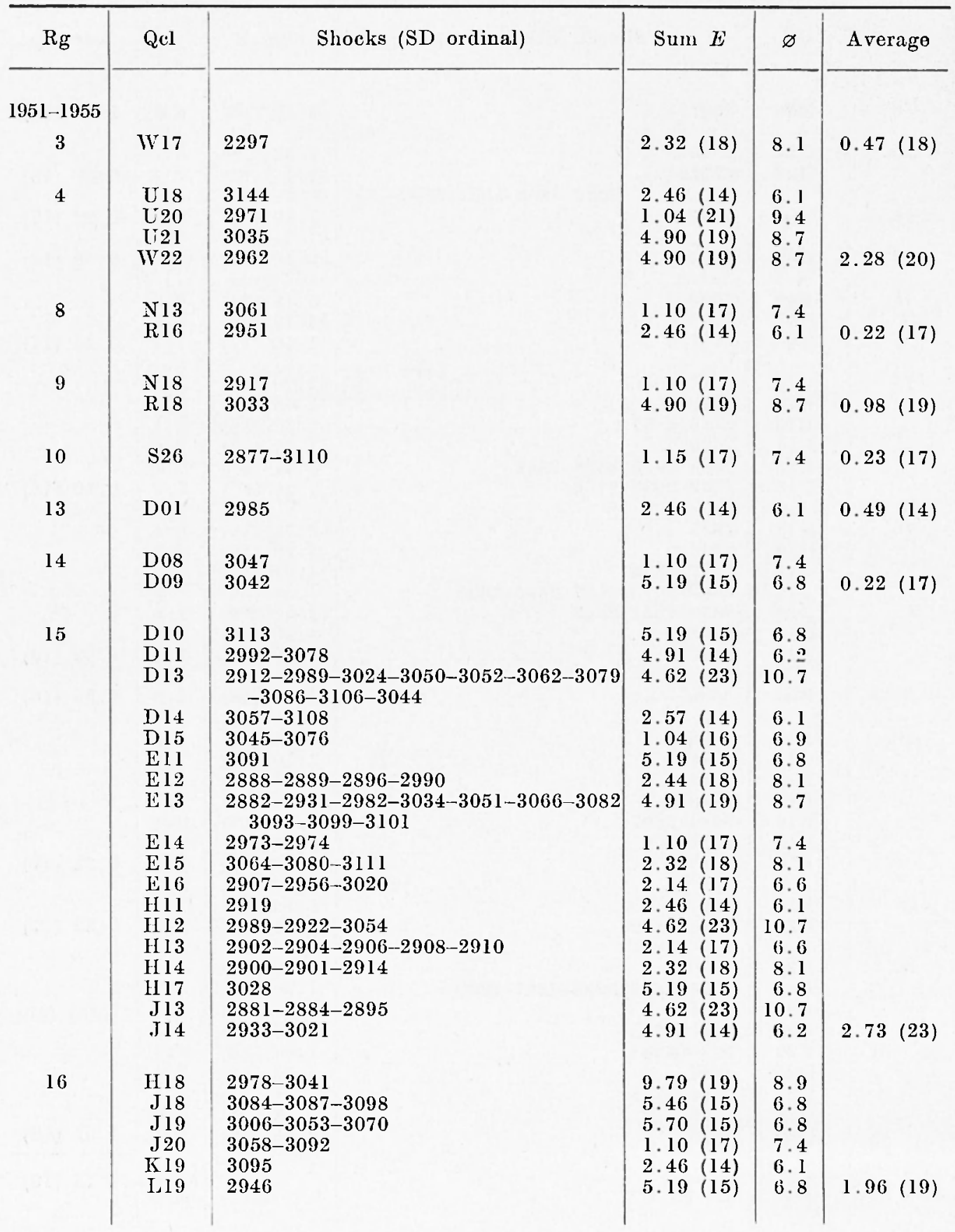


(Tab. V, cont.)

\begin{tabular}{|c|c|c|c|c|c|}
\hline $\mathrm{Rg}$ & Qel & Shocks (SD ordinal) & Sum $E$ & $\varnothing$ & Average \\
\hline 18 & $\mathrm{Col}$ & $3015-3019$ & $4.9 \mathrm{I}(\mathrm{l} 4)$ & 6.2 & $0.98 \quad(19)$ \\
\hline 19 & $\begin{array}{l}\mathrm{C} 07 \\
\mathrm{C} 08\end{array}$ & $\begin{array}{l}2976 \\
3048\end{array}$ & $\begin{array}{l}4.90(19) \\
5.19(15)\end{array}$ & $\begin{array}{l}8.7 \\
6.8\end{array}$ & $0.98 \quad(19)$ \\
\hline 20 & $\begin{array}{l}\text { A } 11 \\
\text { A } 15 \\
\text { B } 12 \\
\text { B } 13 \\
\text { B } 16 \\
\text { C } 11 \\
\text { C } 15\end{array}$ & $\begin{array}{l}3056 \\
3004 \\
2873-3062 \\
3090 \\
3049 \\
3023 \\
2885-2936-3036-3055\end{array}$ & $\begin{array}{l}2.46(14) \\
5.19(15) \\
1.10(17) \\
5.19(15) \\
2.46(14) \\
5.19(15) \\
5.94(15)\end{array}$ & $\begin{array}{l}6.1 \\
6.8 \\
7.4 \\
6.8 \\
6.1 \\
6.8 \\
6.8\end{array}$ & $0.26 \quad(17)$ \\
\hline 21 & $\begin{array}{l}\text { B20 } \\
\text { D2 } 1\end{array}$ & $\begin{array}{l}2987 \\
2999\end{array}$ & $\begin{array}{l}1.10(17) \\
1.10(77)\end{array}$ & $\begin{array}{l}7.4 \\
7.4\end{array}$ & $0.44 \quad(17)$ \\
\hline 22 & $\begin{array}{l}\mathrm{C} 23 \\
\mathrm{C} 24 \\
\mathrm{C} 27 \\
\mathrm{D} 23\end{array}$ & $\begin{array}{l}3068-3069 \\
3072-3073-3075-3100 \\
3025 \\
3071-3094\end{array}$ & $\begin{array}{l}2.19(22) \\
5.14(19) \\
1.04(21) \\
4.90(19)\end{array}$ & $\begin{array}{r}10.1 \\
8.8 \\
9.4 \\
8.7\end{array}$ & $0.49 \quad(22)$ \\
\hline $1956-1960$ & & & & area & $2.78(23)$ \\
\hline 4 & $\begin{array}{l}U 19 \\
U 20 \\
U 21\end{array}$ & $\begin{array}{l}3121 \\
3229 \\
3201\end{array}$ & 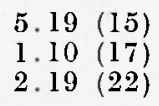 & $\begin{array}{r}6.8 \\
7.4 \\
10.1\end{array}$ & $0.42(22)$ \\
\hline 8 & $\begin{array}{l}K 17 \\
\mathrm{I} 15\end{array}$ & $\begin{array}{l}3188 \\
3156\end{array}$ & $\begin{array}{ll}1.10 & (17) \\
2.46 & (14)\end{array}$ & $\begin{array}{l}7.4 \\
6.1\end{array}$ & $0.22(17)$ \\
\hline 10 & $\begin{array}{l}\mathrm{R} 24 \\
\mathrm{~S} 25\end{array}$ & $\begin{array}{l}3305 \\
3192-3193\end{array}$ & $\begin{array}{ll}2.46 & (14) \\
2.20 & (17)\end{array}$ & $\begin{array}{l}6.1 \\
7.8\end{array}$ & $0.44(17)$ \\
\hline 11 & $\begin{array}{l}\text { J04 } \\
\text { L02 }\end{array}$ & $\begin{array}{l}3178 \\
3232\end{array}$ & $\begin{array}{l}1.10(17) \\
5.19(15)\end{array}$ & $\begin{array}{l}7.4 \\
6.8\end{array}$ & \\
\hline 13 & $\begin{array}{l}\mathrm{D} 01 \\
\mathrm{D} 03\end{array}$ & $\begin{array}{l}3127-3218 \\
3142\end{array}$ & $\begin{array}{l}5.43(15) \\
1.10(17)\end{array}$ & $\begin{array}{l}6.8 \\
7.4\end{array}$ & $0.22(17)$ \\
\hline 14 & $\begin{array}{l}\text { D09 } \\
\text { E06 }\end{array}$ & $\begin{array}{l}3244-3251 \\
3134-3206\end{array}$ & $\begin{array}{l}1.10 \\
1.04\end{array}$ & $\begin{array}{l}7.4 \\
9.4\end{array}$ & $0.20(21)$ \\
\hline 15 & $\begin{array}{l}\text { D } 14 \\
\text { D } 15 \\
\text { D17 } \\
\text { E } 12 \\
\text { E13 } \\
\text { E } 14 \\
\text { E } 16 \\
\text { E } 17\end{array}$ & $\begin{array}{l}3136-3187 \\
3146-3149 \\
3125 \\
3148 \\
3128-3129-3131-3254 \\
3126 \\
3132-3151-3246 \\
2489-3141\end{array}$ & $\begin{array}{l}1.10(17) \\
1.10(17) \\
1.10(17) \\
5.19(15) \\
1.04(21) \\
2.46(14) \\
1.20(17) \\
1.15(17)\end{array}$ & $\begin{array}{l}7.4 \\
7 \cdot 4 \\
7.4 \\
6.8 \\
9.4 \\
6.1 \\
7.4 \\
7.4\end{array}$ & \\
\hline
\end{tabular}


(Tab. V, cont.)

\begin{tabular}{|c|c|c|c|c|c|}
\hline $\mathrm{Rg}_{g}$ & $\mathrm{Qel}$ & Shocks (SD ordinal) & Sum $E$ & $\varnothing$ & Average \\
\hline & $\begin{array}{l}113 \\
\text { H15 } \\
\text { H17 }\end{array}$ & $\begin{array}{l}3190 \\
3147-3196 \\
3243\end{array}$ & $\begin{array}{l}2.46(14) \\
5.44(15) \\
5.19(15)\end{array}$ & $\begin{array}{l}6.1 \\
6.8 \\
6.8\end{array}$ & $0.21 \quad(21)$ \\
\hline 16 & $\begin{array}{l}\text { H1 } \\
\text { H19 } \\
\text { J18 } \\
\text { J } 19 \\
\text { K } 19 \\
\text { L19 } \\
\text { H20 }\end{array}$ & $\begin{array}{l}3172 \\
3210-3249 \\
3202-3235 \\
3179-3180-3215 \\
3177-3181-3236-3238 \\
3189 \\
3211\end{array}$ & $\begin{array}{l}2.46(14) \\
1.61(15) \\
2.43(18) \\
2.43(18) \\
2.45(18) \\
2.32(18) \\
1.10(17)\end{array}$ & $\begin{array}{l}6.1 \\
6.5 \\
8.1 \\
8.1 \\
8.1 \\
8.1 \\
7.4\end{array}$ & $1.92(18)$ \\
\hline 18 & $\begin{array}{l}\mathrm{B} 01 \\
\mathrm{~B} 04 \\
\mathrm{C} 02 \\
\mathrm{C} 05 \\
\mathrm{C} 06\end{array}$ & $\begin{array}{l}3115 \\
3191 \\
3138-3234 \\
3164 \\
3163\end{array}$ & $\begin{array}{l}2.46(14) \\
2.46(14) \\
1.04(16) \\
5.19(15) \\
1.10(17)\end{array}$ & $\begin{array}{l}6.1 \\
6.1 \\
6.8 \\
6.8 \\
7.4\end{array}$ & $0.24(16)$ \\
\hline 19 & В07 & 3252 & $4.90(19)$ & 8.7 & $0.98 \quad(19)$ \\
\hline 20 & $\begin{array}{l}\text { A } 14 \\
\text { A } 15 \\
\text { B } 12 \\
\text { B13 } \\
\text { B14 } \\
\text { C12 } \\
\text { C14 } \\
\text { C15 } \\
\text { C16 }\end{array}$ & $\begin{array}{l}3220-3221 \\
3155 \\
3118 \\
3153 \\
3143-3224-3255 \\
3175 \\
3119-3168-3170-3199 \\
3209-3214 \\
3171\end{array}$ & $\begin{array}{l}4.90(19) \\
1.10(17) \\
2.46(14) \\
2.46(14) \\
5.68(15) \\
2.46(14) \\
7.48(14) \\
5.44(15) \\
2.46(14)\end{array}$ & $\begin{array}{l}8.7 \\
7.4 \\
6.1 \\
6.1 \\
6.8 \\
6.1 \\
6.3 \\
6.8 \\
6.1\end{array}$ & $0.98 \quad(19)$ \\
\hline 21 & $\begin{array}{l}\text { B } 19 \\
\text { C17 }\end{array}$ & $\begin{array}{l}3158-3227 \\
3162\end{array}$ & $\begin{array}{l}4.90(19) \\
2.32(18)\end{array}$ & $\begin{array}{l}8.7 \\
8.1\end{array}$ & $0.98 \quad(19)$ \\
\hline 22 & $\begin{array}{l}\text { B22 } \\
\text { B23 } \\
\text { B27 } \\
\text { B29 } \\
\text { B 30 } \\
\text { C23 } \\
\text { C24 } \\
\text { C25 } \\
\text { C28 } \\
\text { C29 } \\
\text { C30 } \\
\text { D23 } \\
\text { D 24 } \\
\text { D27 } \\
\text { D } 30 \\
\text { E } 25\end{array}$ & $\begin{array}{l}3161 \\
3083 \\
3043 \\
3228 \\
3032 \\
3120-3123-3167-3203-3240 \\
3114-3176 \\
3226 \\
3133 \\
3285-3288 \\
3213-3269 \\
3197 \\
3174 \\
3229 \\
2775 \\
3242\end{array}$ & $\begin{array}{l}4.90(19) \\
5.19(15) \\
2.32(18) \\
4.90(19) \\
4.90(19) \\
9.38(18) \\
5.44(15) \\
2.32(18) \\
2.32(18) \\
4.92(14) \\
1.04(21) \\
1.10(17) \\
1.10(17) \\
1.10(17) \\
2.46(14) \\
2.46(14)\end{array}$ & $\begin{array}{l}8.7 \\
6.8 \\
8.1 \\
8.7 \\
8.7 \\
8.4 \\
6.8 \\
8.1 \\
8.1 \\
6.2 \\
9.4 \\
7.4 \\
7.4 \\
7.4 \\
6.1 \\
6.1\end{array}$ & $2.32(20)$ \\
\hline & & & & \multicolumn{2}{|c|}{ area $=5.06(21)$} \\
\hline
\end{tabular}


Magnitude, $m$, was deduced from $I_{o}$, thus these values cannot be accepted individually. The groups in steps of a half $m$ unity are valid as probable qualitative evaluations and they serve as comparisons. The area was divided in quadricles of one half a degree in latitude and longitude to include the error of the epicentral determinations. The focal depth proceeds from various determinations quoted in the Spanish Seismic Catalogue; so classified, they rould be aceepted for seismicity.

During the study, the writer belives that some interesting problems have been noticed. These doubtful points are especially useful to confirm or rectify the suggestions made on the basis of the attained results.

Since 1961, the Spanish Central Seismological Laboratory (LCSS) prepare a local earthquakes bulletin for the same area as the one studied here. These data might be utilized in the future to obtain a new frequency and magnitude regression; to study the Betican and Algerian shocks sequences, especially in the Alboran sea and in Southern Andalucia; an analysis of the possible new intermediate foci and their sventual correlation with other shallow ones, as well as the sequence and perhaps the correlation between the shocks corresponding to the one or to the other side of the territory and even outside of it, in the Mediterranean Geosyncline.

It is desirable to have, as soon as possible, a gravimetric map of the isostatic anomaly and a geomagnetic map of the field isoporic eurves, both for the whole area. Also, in order to know the region, it is necessary to have an actual crustal motions map, and seismic profiles by means of sub-aquatic explosions; efforts to observe the submerged platform which should inform us of the maritime tectonies and portable short period seismograph equipment could contribute very much to define the true seismic characteristies of the region. The seismic lagoon in Ibiza and the belt separating the $D$ and $E$ zones, as well as the (perhaps possible) identification of the true shape of the Seno Gaditano Oval and of the Alboran Fault, or the rough draft of the Betican halfclose are the main question which invite clarification.

\section{VI. - ACKNOWLEHGMENT.}

The present paper has been sponsored by the Air Force of Scientific Researeh, OAR, through the European Oftice of Aerosprace Rescarch, 
according to the contract $A F 61(052)-65 \%$, as part of the Advanced Research Project Agency's Project Vela-Uniform, of the U.S. Air Foree.

\section{REWERENEN}

Rey Paston A., Traits sismiques de la Peninsule Iberique. IGC, Madrid, (1927).

-... Oroquis sismolectonieo de la Peninsula Iberica. L(G(, Madrid, (1927).

TERalli T., Colloids and seismology. BERI, XIII, 3, Tokyo, (1935).

Lozaxo Galvo L., Las anomalias isostatieas en España según la teoria de Liry. RG, 7, 27, Madrid, (1948).

REY Pastor A., Las costas mediterraneas de la l'eninsula Mispaniea. Ra, 7, 26, Madrid, (1948).

Rotne .J. P., Tremblements de terre el anomalies magnetiques. GPA, XII, Milano, (1948).

Sans Huelin (x., Lozano Calvo L., has determinaciones de la gravedad en España y el elipsoide terrestre más aproximado al geoide que se deduce de aquellas. IGC, Madrid, (1948).

BENIOFF H., Seismic evidence for the faull origin of oceanic deeps. BGSA, 60, Washington, (1949).

Chardien Ch., Liapport de la Seismologie, de la Gravimetrie el de la Geodesie sur la connaissence de l'ecorce lerrestre en Belgique. BARB, 5, XXXVII, Bruxelles, (1951).

Heiskance W., (Translation by sans Iluelin from the report presented at IIelsinky, 1948) Sobre la estructura isostatica de la corleza lerrestre. IGC, Madrid, (1951).

Lozano Canvo L., Formule de la gravilé normal en Espagne. IGC, Madrid, $(1951)$.

Boneli. J.. Es'teban Carrasco [., Resullados provisionales del estudio de caracler sismico de la falla del (iuadalquivir. IGC, Madrid, (1953).

Bonesti J., Sobre un esludio de caracter sísmico de la falla del Guadalquivir. IUGG, 2, 2, Paris, (1953).

BATr M., Seismicity of Fenoscandia and related problems. IUGG, 2, 2, Paris, (1953).

Cirarler Ch., Les secouses seismiques en 19.51 el la struchure de l'ecorce terrestre en Belgique. IUGG, 2, 2, Paris, (1953).

Due A., s.J., La sismicidad del Sudeste de España. ITGG, 2, 2, Paris, (1953). Peterschutr E., La seismicité de la France. IlGG, 2, 2, Paris, (1953).

Pinar N., Relation entre la Tectonique el la Seismologie de la Turquie. IUGG. 2, 2, Paris, (1953). 
Rey Pastor A., La sismicidad de la Peninsula Iberica. IUGG, 2, 2, Paris, (1953).

Gutenberg B., Richter C. F., Seismicity of the Earth. Princeton Un, N.Y. (1954).

Martín Royéro J., Contribución al estudio sobre la sismicidad del Atlantico. MIGC XXIV, VI, Madrid, (1954).

Katz S., Seismic study of crustal structure in Pensilvania and New York. BSSA, 45, 4, (1955).

BYERLY P., The Fallon-Stillwater earthquales of July 6, 1954 and August 23,1954 . BSSA, 46, 1, (1956).

St. AynND P., Two proposed measures of seismicity. BSSA, 46, 1, (1956).

IIeiskanen W. A., Vening Meinesz F. A., The Earth and its gravity field. Mc Graw-Ilill, BCI, New York, (1958).

I. XOPOFF L., Energy release in earthquakes. GJ, 1, (1958).

Martín Rounro J., La region sísmica del Seno Gaditano. RC, Madrid, (1958).

Alyela A., Puyal V., Mapa sismotectónico de España Peninsular y Baleares. IGC \& IGM, Madrid, (1960).

KarNIK V., Seismicity of Europe. (Progress report II), IUGG, 9, (1960). PaEz A., Raport national de travaux geodethiques". SPUIGG, Lisboa, (1960).

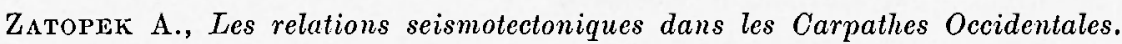
IGATS, 135, Praha, (1960).

Adams L. H., Davis B. L., Rapidly running transition at high preasure. Proc. NAS, 48, (1962).

Beloussov V. V., Basic problems in Geotectonics. Me Graw-Hill, N.Y., (1962).

- Sorsky A. A., The seismotectonic map of Europe. IPEAS, Moscow, (1962).

Lozano Calvo L., Mapas para el calculo de las reducciones topo-isostáticas. IGC, Madrid, (1962).

Soetadi R., Seismic zones in Indonesia. GN, 2. DMG, Djakarta, (1962).

Evison F. F., Earthquakes and faults. BSSA, 53, 5, (1963).

Galanopoulos A. G., On mapping of seismic activity in Greece. AG, XVI, 1, Roma, (1963).

Marcelli L., Pannocchia G., L'altività sismica nella zona delle Sorgenti del Peschiera. AG, XVI, 4, Roma, (1963).

PeÑa V., La formación del Mapa Magnetico y primer resultado comparativo de los Observatorios. IGC, Madrid, (1963).

Sykes L. R., Seismicity of the South Pacific Ocean. JGR, 68, 21, (1963).

KARNIK V., Seismicity of Europe (Progress Report IV). ISEEI, Tokyo, (1964).

NiazI M., Seismicity of Northern California and Western Nevada. BSSA, 54, 2, (1964). 
Abbreviazioni:

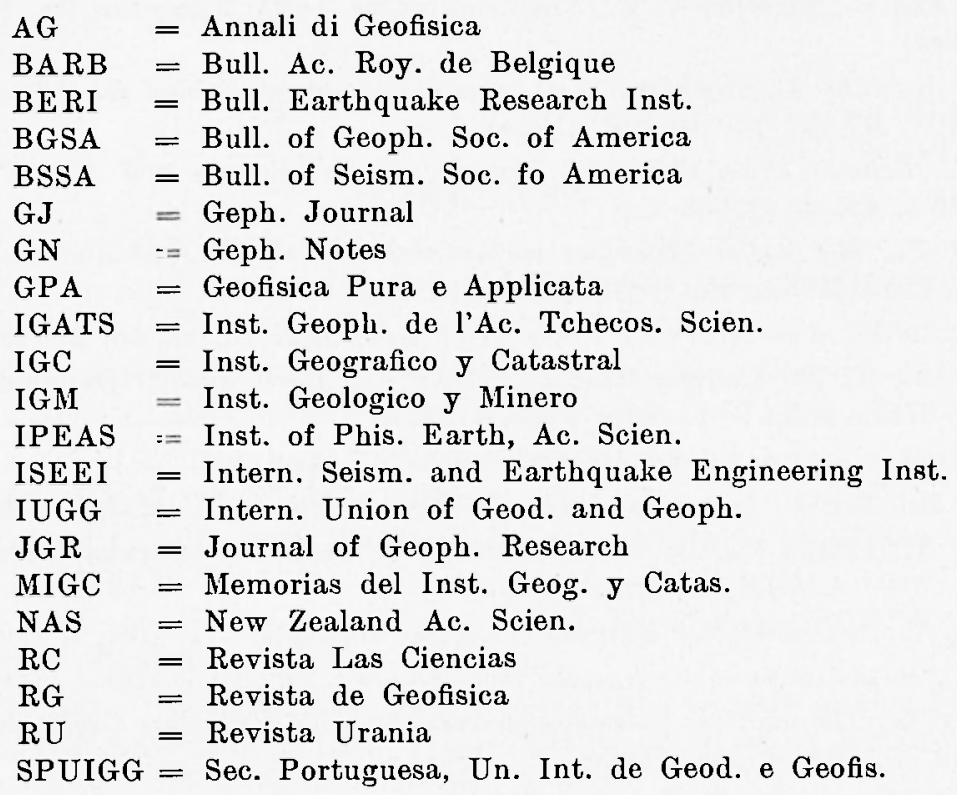

